

\section{XXI11A.5. 11}

IVER

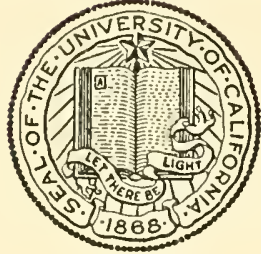

THE LIBRARY

OF

THE UNIVERSITY

OF CALIFORNIA

LOS ANGELES 

Digitized by the Internet Archive in 2008 with funding from Microsoft Corporation 
THE LAND AND THE PEOPLE 


\section{OTHER BOOKS IN THE SERIES}

LABOUR AND INDUSTRY. (Fust out.) SOME FRENCH CATHEDRALS. (Fust out.) THE POWERS AND AERONAUTICS. THE RIVIERA GOLF COURSES. 


\title{
THE LAND
}

AND THE PEOPLE

\section{The Tímes \$cries}

\author{
LONDON : \\ JOHN MURRAY, ALBEMARLE STREET, W. \\ I9I 3
}


ALL. RIGHTS RESERVED 


\section{HD \\ 5.95 \\ 148}

\section{CONTENTS}

CHAPTER I

PAGE

WHAT IS THE LAND QUESTION - - - - I

CHAPTER II

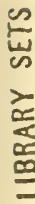

POPULATION - $\quad$ - $\quad$ - $\quad$ - $\quad$ - $\quad$ - $\quad$ - 8

CHAPTER III

A COMPARISON WITH FOREIGN COUNTRIES - - 17

CHAPTER IV

AGRICULTURAL PRODUCTION - $\quad$ - $\quad$ - $\quad 27$

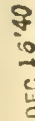

is

CHAPTER V

labourers' WAges - $\quad$ - $\quad$ - $\quad$ - $\quad 43$

CHAPTER VI

IOUSI:TG

$+\quad-\quad+\quad-54$

CHAPTER VII

SMALL HIOLDINGS - $\quad-\quad-\quad+\quad-\quad-66$

CHAPTER VIII

LAND OWNERSHIP - $\quad$ - $\quad$ - $\quad$ - $\quad$ - 80 
All the books in this Series are reprinted from Articles which have appeared in Tbe Cimes, and are issued under the auspices of that newspaper. 


\section{THE}

\section{LAND AND THE PEOPLE}

\section{CHAPTER I}

\section{WHAT IS THE LAND QUESTION ?}

UNDER the title of the land question the condition of agriculture and of the agricultural population has lately sprung into a leading place in home politics. In the following chapters an attempt is made to present exact information relating to the more important points involved, not for controversial purposes, but to serve as an introduction to the subject and to furnish a background of facts which may assist in its intelligent discussion and in the appreciation of any additional facts which may be brought forward. It is desirable to begin by having a clear idea of what is meant by the land question and how the various aspects of it are related. 


\section{WHAT IS THE LAND QUESTION ? \\ What is the Land Question?}

'The fundamental question is whether the best use is being made of the soil, and this question has two aspects, which are closely connected but not the same. They are population and production. That is to say, we may regard agriculture as an occupation and judge it by the population it maintains, or as a means of production and judge it by the amount of food it produces for the whole community. These are the fundamental questions because they have to do with life ; and the final aim of all effort, whether individual or social, is life itself--its preservation and increase in quantity or quality or both. Mankind always praises the preservation, the increase, and the improvement of life, and condemns the opposite. The complaint about agriculture is that as an occupation it fails to maintain life both in quantity and quality, and that as a productive agency it might do more to feed the nation than it does. Sometimes stress is laid on the one and sometimes on the other; but they are generally regarded as involving each other more or less. Just at present the former complaint seems to be more prominent. If the rural population were increasing in number and improving in quality there would be no land question, or none in the sense of an acute political issue. What catches the ear is the cry that rural life 
is declining, absolutely or relatively, in both respects. Particular questions, such as housing and wages, are secondary and only of importance in so far as they bear on the main point. But there is, as usual, a strong tendency to exalt them into the first place and regard them as objects to be pursued for their own sake. That may be quite legitimate, but it is not the land question.

\section{Population.}

As for the facts in regard to population, we are wont to measure, or try to measure, life as we do everything, by physical standards on the principle pointed out the other day by M. Bergson ; and so far as quantity is concerned the matter is simple enough. We have the Census, which tells us the number of persons who live by agriculture and we can see whether they are increasing or diminishing. Quality is a more difficult matter; it cannot really be measured, and that is why civilisation is a riddle. Optimists are people who like to think that quality in general is improving and they are quite prepared to sacrifice quantity to that assumption. Pessimists think the contrary; but nobody knows. In this state of uncertainty what happens is that people fall back on the physical element, which is more susceptible of measurement than the others, and assume 


\section{WHAT IS THE LAND QUESTION ?}

that they go with it, though nothing is more obvious than that they often do not. But even physical quality is difficult to measure, and we have as yet no standard. So the question is left to inference, and it is urged that the physical conditions of rural life, which can be measured, must entail deterioration or at least prevent improvement. Thus there are two sets of facts to be examined in this connection:-(I) The movement of the agricultural population; (2) the conditions under which they live. But it is to be observed that the relation of these facts to the fundamental problem is very different. The first set directly proves somethingnamely, the diminution of the agricultural population; the second set proves nothing directly, but is connected by inference both with diminution, which is proved, and with deterioration, which is not. The conditions of rural life are commonly assumed to be responsible for both, and proposed measures of reform are based on that assumption; they are expected to increase the quantity and improve the quality of life. From this point of view the land question is narrowed down to higher wages and better cottages.

\section{Production.}

Turning to the other half of the questionthe less prominent but not less important 
problem of production-there has recently been a comprehensive official inquiry in to the agricultural output of Great Britain. Valuable as it may be, it throws little or no light on the situation for lack of a standard of comparison which would show whether agriculture is advancing or receding in this respect. More can be learnt from the returns of what we do not produce but obtain from elsewhere, which go back for many years; and also from those which show the amount of land cultivated and the kind of crops grown. An analogous subject on which full information is available is the number and size of holdings. At the present time productivity is usually regarded as dependent on population. It is assumed as a broad and easy generalisation that if more people lived on and by the land it would produce more. Hence the importance attached to small holdings and intensive cultivation, which would, it is thought, solve both problems at once. It is not easy to say how far this holds good under actual conditions. As a general proposition it is true that production varies with the amount of work put into anything, but the amount of work does not necessarily correspond with the number of persons engaged in it, because the term " work" covers many things besides the main d'ouvre. It cannot be assumed that the productivity of any given piece of land 


\section{WHAT IS THE LAND QUESTION ?}

would be increased by its being split up among a number of people or by the employment of a larger number of persons on it. There is a hidden condition which is taken for granted in all such calculations-the condition " other things being equal." But in practice they very seldom are, and herein lie many fallacies. The test is economic success. Where small holdings, for instance, are successful it may fairly be argued that the soil is being put to a better use by the larger number of persons at work on it and the more intense cultivation applied to it. The conditions required for success are, therefore, an important subject of inquiry. If, on the other hand, small holdings are not successful, while larger ones are, then the interests of agriculture cannot be served by artificially stimulating an inferior form of cultivation.

\section{The True Issue.}

If any justification is needed for these introductory remarks it may be found in the accumulating signs that under the guise of the land question subsidiary issues are about to be pressed upon the country and enveloped in a cloud of confusion in which their bearing on the real point, which is the condition of agriculture as an industry and its contribution to the national economy, is ignored or obscured. The root of the whole 


\section{A SICK INDUSTRY}

matter is that agriculture is, and has long been, a sick industry, and the problem is how to cure it, as an industry, not by treating parts of it, and still less by setting one part against another, but by infusing life into it as a whole. Successful treatment must depend on a right understanding of the nature and extent of the malady. The doctors are gathering round the bed; if they would put their heads together they might do something for the patient. But they seem more likely to offer different remedies, and to spend their time each in proving the advantages of his own and the worthlessness of the others. Some appear to be thinking of something else altogether. The object of this inquiry is to help the public to judge for themselves by presenting the principal facts relating to the state of agriculture and indicating their bearing on proposed remedies. The subject is many-sided and of extreme intricacy owing to the infinite variability of conditions, the innumerable factors involved, and their deep-rooted connection with past history and traditional custom. Comprehensive treatment is out of the question in a limited space, and some subjects are omitted which would be in place in a scheme of reform, but are not essential to an examination of the existing state of things. 


\section{CHAPTER II \\ POPULATION}

THE agricultural population of Great Britain has been declining relatively to the whole for at least a century. We have no valid statistics earlier than I8II, when the second Census was taken. An attempt was made in I8or to ascertain the number of persons employed in agriculture, but the results were so vitiated by defective returns as to be thought invalid. In I8II a change was made and the number of families was obtained instead of persons, and this was continued until $r 8_{4} \mathrm{r}$, when a return was made to the former method of enumerating persons. It was, however, possible to compare I84I with I83I in regard to males over 20; and accordingly the Census report for $185 \mathrm{I}$ gave the following comparative figures, showing the proportion of the agricultural population to the whole at each of the four Censuses:-

\begin{tabular}{cccc|c}
\hline & Year. & & $\begin{array}{c}\text { Percentage of Population } \\
\text { Engaged in Agriculture. }\end{array}$ \\
\hline 1811 & $\ldots$ & $\ldots$ & $\ldots$ & 35 \\
1821 & $\ldots$ & $\ldots$ & $\ldots$ & 33 \\
1831 & $\ldots$ & $\ldots$ & $\ldots$ & 28 \\
1841 & $\ldots$ & $\ldots$ &.. & 22 \\
\hline \multicolumn{1}{c}{8}
\end{tabular}


(Porter in his Progress of the Nation gives 25.93 as the proportion for $\mathrm{I} 84 \mathrm{I}$, but the official estimate, which was drawn up later, must be held more authoritative.) In I 85 I the Census was much extended and improved and comparison with previous years was rendered invalid; but the report for Igor gives the following proportional figures for r $85 \mathrm{r}$ and the subsequent enumerations in England and Wales:

\begin{tabular}{|c|c|c|}
\hline Year. & $\begin{array}{c}\text { Percentage of males } \\
\text { aged ro engaged in } \\
\text { agriculture. }\end{array}$ & $\begin{array}{c}\text { Percentage of females } \\
\text { aged ro engaged in } \\
\text { agriculture. }\end{array}$ \\
\hline $1 S_{5} \mathrm{I} \ldots$ & $23 \cdot 5$ & 2.4 \\
\hline I $\$ 6$ I . . & 21.2 & 1.5 \\
\hline I 87 I $\ldots$ & I 6.8 & 1.0 \\
\hline IS81.. & I 3.8 & 0.6 \\
\hline $1891 \ldots$ & I 1.6 & 0.4 \\
\hline $1901 \ldots$ & $9 \cdot 5$ & 0.3 \\
\hline
\end{tabular}

There has thus been a progressive relative decline since ISII, and possibly from a still earlier date. But it appears that since $\mathrm{I} 82 \mathrm{I}$ there has also been a progressive absolute decline. Previously the agricultural population had continued to increase in spite of the industrial expansion, then at its height, and the urban movement. This was due to the steady extension of agriculture under the Enclosure Acts from the middle of the $\mathrm{r} 8 \mathrm{th}$ century onwards and the improvement in methods of cultivation, of which the Census report of 185 I observes :- 
“. . After I75I great numbers of them (landed proprietors) devoted intelligence and capital to the improvement of their estates. They encouraged societies of agriculture. The farmers adopted new processes. The increased produce of the farm was improved in quality; commons were enclosed; marshes were drained; machinery was introduced. The breeds of cattle, sheep, and horses were sensibly improved; and an impulse was thus given to the cultivation of the finest part of agricultural science."

The result of all this activity, which is described in detail by Mr. R. E. Prothero in English Farming Past and Present, was that the land increased greatly both in productivity and in population. It was able to feed a nation growing at a more rapid rate than has ever since been reached and to give employment and maintenance to an increasing number of persons. As already explained, we have no figures earlier than I8II, but between that year and I82I the number of families engaged in agriculture increased in England from 697,353 to 773,732, and in Great Britain from 895,998 to 978,656 . During this decade the population of England advanced at the rate of IS per cent., which has never since been approached.

\section{Absolute Decline.}

After $182 \mathrm{I}$, however, the relative decline, 
noted above, became absolute. Between I $82 I$ and IS3I the agricultural families fell from 773,732 to 761,348 in England, and from 978,656 to $96 \mathrm{I}, \mathrm{I} 34$ in Great Britain. It was a period of extreme agricultural depression, in which many farmers and smallowners were ruined and much land went out of cultivation, while the condition of labourers became pitiable. The movement of the population during the ensuing 20 years cannot be statistically given in the same terms on account of changes in the Census, as already explained; but from $x_{5}$ I onwards we have a continuous record for England and Wales. It is set out in the Census Report for IgOI in a comparative table in which allowance has been made for minor changes in enumeration.

ENGLAND AND IVALES.

\begin{tabular}{|c|c|c|c|c|}
\hline \multicolumn{2}{|c|}{ Year. } & & $\begin{array}{l}\text { Persons Engaged. } \\
\text { in Agriculture. }\end{array}$ & Decrease. \\
\hline $1851 \ldots$ & $\ldots$ & .. & $1,712,739$ & - \\
\hline $1861 \ldots$ & . & .. & $1,655,178$ & 57,561 \\
\hline $1871 \ldots$ & .. & .. & $1,45^{6,971}$ & 198,207 \\
\hline $1881 \ldots$ & . & .. & $1,352,389$ & $10_{4}, 5^{82}$ \\
\hline $1891 \ldots$ & . & .. & $1,284,981$ & 67,408 \\
\hline $1901 \ldots$ & . & .. & $1,192,167$ & $9^{2}, 8$ I 4 \\
\hline
\end{tabular}

The total decrease in 50 years was 520,572 ; and of that number 390,902 were males and I29,670 females. The fall between I87 I and I88I is somewhat higher than it should be 
because " retired " persons, who had previously been included, were omitted in I88I. But that does not affect the change recorded in any other intercensal period or the general lesson of a large and continuous decline. The movement recorded for the United Kingdom during the same 50 years was from $3,453,500$ to $2,262,600$, or a decrease of I,I90,900. The foregoing figures include farmers and their families and others; but if the " workers on farms " alone are taken the decline is much more rapid, as the following table shows :-

ENGLAND AND WALES.

\begin{tabular}{|c|c|c|c|c|}
\hline \multicolumn{3}{|c|}{ Year. } & $\begin{array}{c}\text { Workers on } \\
\text { Farms. }\end{array}$ & Decrease. \\
\hline I $85 \mathrm{I} \ldots$ & . & $\cdots$ & $\mathrm{I}, 37^{6,05 \mathrm{I}}$ & - \\
\hline I 86 I .. & . & . & I,296,805 & 79,246 \\
\hline I 87 I . . & .. & .. & $1,073,084$ & 223,721 \\
\hline I 88 I .. & .. & . & 965,2 I 7 & 107,867 \\
\hline I 89 I . . & .. & . & 866,034 & $99, \mathrm{I} 8_{3}$ \\
\hline I 901 . . & .. & . & 727,140 & I 38,894 \\
\hline
\end{tabular}

The total decrease in the $5^{\circ}$ years was 648,9 II, or 47 per cent. ; 517,438 were males and I3I,473 females. As the process has been going on since Igor, we may safely conclude that since $\mathrm{I}_{55} \mathrm{I}$ the number of workers employed on the land in England and Wales has fallen by one-half. The Census of Production returned the number of persons employed permanently and temporarily, including 
members of occupiers' families, in I908 as I,I28,000 in England and Wales and $\mathrm{I}, 340,000$ in Great Britain. Excluding occupiers' families the numbers were 722,000 and $8_{3} 8,000$; excluding the temporarily employed they were 576,000 and 67x,000

\section{Causes of Decline.}

We are at present only setting out the statistical evidence of decline, but in connection with the tables given above it is desirable to add here some observations on the causes. The fall is seen to be continuous but by no means uniform; it varies widely in different decades, and an examination of the conditions prevailing at different times throws some light on causation. One point of interest emerges at once in regard to the influence of wages. The movement of wages shows no correspondence at all with rural migration. By far the largest decrease occurred in I86I-7I, when wages were rising. Between I8SI and ISgI, on the other hand, wages were falling and migration fell too. It might perhaps be argued from this that the movement of wages was the consequence, not the cause, of migration, and that the former rose with a diminished supply of labour. There is probably something in this theory, but it does not always hold good. In I 85I-6r, when the least migration took place, wages 
rose more rapidly than in the period of most migration. In any case, the statistics make it impossible to contend that migration has followed the state of wages. Nor can any correspondence be traced between depopulation and the conversion of small into large farms. When the greatest decline took place the number of farmers was increasing. In the only decade when a distinct drop occurred in the number of farmers - namely, in I87I-8I, when they declined from 250,000 to 224,000 - the decrease of labourers was less than half that which occurred in IS6I-7I, when the number of farmers increased. In like manner the demand for labour in towns and the attraction of high wages fail to account for the facts, though some correspondence can be traced. For instance, rural migration fell off markedly in the very depressed industrial period between ISSI and I89I; but, on the other hand, I86I-7I was also mainly a depressed decade, and I87I-8I one of unequalled prosperity until towards its close; yet the rural decline was more than twice as great in the former. Nor is the exceptional decrease in I86I-7I accounted for by the conversion of arable into pasture land. The statistical tables given by Mr. Prothero show that between I 866 and I87 the area under corn crops in England and Wales increased from $7,886,244$ to 
$8,244,392$ acres, though the area of permanent grassland also increased by some 350,000 acres. The great reduction of arable land did not begin until the next decade.

\section{Imports, Prices, And Machinery.}

Certain changes, however, did coincide with the migration of IS6I-70, and the explanation of its exceptional character may, perhaps, be found in them. Imports of agricultural produce were then rising rapidly. The average annual amount of wheat imported rose in millions of cwt. from $I 8$ in I $856-60$ to 28 in $I 86$ I- 65,32 in IS66-70, and $4+$ in $I 87 I-75$; imports of barley rose at the same time from 5.7 to I million cwt., and of oats from 4.8 to Ir.6 million cwt. Also the price of wheat fell heavily, and was relatively very low in IS63-4-5, though it rose again and stood high in IS67-8. Mr. Prothero says that after I 862 the tide of agricultural prosperity ceased to flow. And it was just at this time that machiney began to come in on a large scale. Its use was not yet general, but enterprising farmers took it up actively and were stimulated, no doubt, by the conditions just mentioned. They got rid of as many men as they could and only retained the permanent hands. In the official inquiry into the Decline of the Agricultural Population carried out by the Board of Agriculture in 1906 ma- 
chinery emerges as the principal cause. This inquiry only covers the period I88I-I906, but the stress laid on machinery confirms the evidence of its influence in the more rapid migration of I86I-70. It is not a first cause. These are to be found in agricultural depression, which set in heavily after I874, falling prices, and rising imports. The farmer in trying to meet these conditions found two weapons to his hand-machinery and the conversion of arable into pasture land; and both have been steadily applied on an extending scale. But machinery appears to be the more important of the two, and it affects dairy farming as well as crop raising.

These have constituted the principal vis a tergo driving labourers off the land. The vis a fronte has been furnished by the attractions of other industries and other countries. It has operated less steadily than the other, being subject to fluctuations due to the state of trade, the demand for labour in other industries, and the activity of emigration. Recently, for instance, the expansion of Canada has proved a powerful attraction. Lack of housing is another factor which has exercised a considerable, though not a general, influence in recent years, having been brought into play by the rising standard of requirements. To some of these points we shall return later on. 


\section{CHAPTER III}

\section{A COMPARISON WITH FOREIGN COUNTRIES}

THE previous chapter dealt with the decline of the agricultural population in Great Britain. There is nothing new in this. Attention has often been drawn to the fact, which is recognised in a general way, though it is not generally realised, how long the process has been going on and how far it has gone. But the state of this country, as compared with others, is not realised at all, and the facts contained in the present chapter will be new to most readers. They are of great importance and deserve the fullest recognition, for it is only by comparison that the strange and unique position we occupy among the nations in this respect is revealed. There is a vague but comfortable impression that, however regrettable the decline of our agricultural population may be, the same thing is going on everywhere else and our neighbours are in much the same state as ourselves. For instance, the Departmental Committee of Igo6 put a comforting paragraph to that effect in its report, and in a quite recent book on the land question by a barrister and responsible writer the assertion 
is lightly made that in France " the tentacles of the great towns have sucked in the agricultural labourer almost, if not quite, as voraciously as they have in England." It is true that in most countries a process of urbanisation is going on and the agricultural population is declining relatively to the industrial and commercial, but the following comparative statistics show the vast difference between this country and all others for which information is available :-

\begin{tabular}{|c|c|c|}
\hline Country and Year. & $\begin{array}{l}\text { Percentage of } \\
\text { occupied popula- } \\
\text { tion engaged in } \\
\text { Agriculture, For- } \\
\text { estry, \& Fishing. }\end{array}$ & $\begin{array}{l}\text { No. of inhabi- } \\
\text { tants per sq. } \\
\text { kilometre. }\end{array}$ \\
\hline $\begin{array}{l}\text { Hungary (I900) } \\
\text { Austria (I900) } \\
\text { Italy (I90I) }\end{array}$ & $\begin{array}{l}69.7 \\
60.9 \\
59.4 \\
58.3 \\
49.8 \\
48.2 \\
42.7 \\
41.0 \\
35.9 \\
35.2 \\
30.9 \\
30.7 \\
21.1\end{array}$ & $\begin{array}{r}64 \\
95 \\
121 \\
19 \\
13 \\
71 \\
74 \\
7 \\
12 \\
120 \\
91 \\
172 \\
252\end{array}$ \\
\hline $\begin{array}{l}\text { United Kingdom } \\
\text { (I90I) . } \because \text {. } \\
\text { Great Britain (I90I) } \\
\text { England and Wales } \\
\text { (I90I) .. . . . }\end{array}$ & $\begin{array}{r}13.0 \\
9.2 \\
8.8\end{array}$ & $\begin{array}{l}144 \\
177 \\
239\end{array}$ \\
\hline
\end{tabular}


These figures show the position reached at the time of the last census available in each country; but for full appreciation of the facts account must be taken of the movement in each. We have seen above that with us agriculture has been declining in relative importance for a century, and that the agricultural population has been decreasing absolutely for something like So years. The only other countries in the above table showing an absolute decrease between the last two censuses are Austria, Switzerland, and Norway. In Austria the agricultural section dropped by about 260,000 between $I 890$ and rooo ; but it is still so preponderant (6I per cent.) that the difference is immaterial. Austria has still over eight million persons engaged in agriculture, against three millions in industry and mining. In Switzerland agriculture lost from 6,000 to 7,000 persons between $\mathrm{I} 888$ and 1900 . This is a relatively large number for its small population, which is considerably less than that of London, and indicates a rapid process of conversion. It is an interesting, but little known, fact that Switzerland has in recent years been more rapidly industrialised than any other country with one exception, and now takes second place to Great Britain in regard to the proportion of persons engaged in industry. The exception just mentioned is Norway, where 
between IS9I and I900 agriculture lost 24,660 persons out of a total population of $2,358,000$. This brought the proportion of occupied persons down from 49.6 per cent. to 4I per cent., the largest drop recorded in any country.

\section{Our Great Industrial Rivals.}

We now come to the countries in which a relative but not an absolute decline has taken place ; and these include our greatest industrial rivals. In Germany between IS95 and I907 agriculture dropped from 37.5 per cent. to 35.2 per cent. of the total occupied; but the number of persons occupied in agriculture increased by $1,590,000$. In the United States the figures are curiously close to those for Germany. Between I89o and I9oo agriculture dropped from 38.0 per cent. to 35.9 per cent., but rose numerically by I,886,000. In Belgium during the same period the drop was from 22.9 per cent. to 2I.I per cent., but with an actual increase of 48, I20. In Holland, Sweden, and Hungary also a numerical increase with a small relative decrease was recorded. None of these countries, in which the agricultural population is still increasing, can be said to be in the same category with Great Britain, though some of them may be on the way towards it. 
Where Agriculture is Advancing.

There remain Russia, France, Italy, and Denmark. In Russia apparently only one occupational census has been taken, so that the movement cannot be stated. The agricultural population is naturally much larger in Russia than in any other Western State. In $\mathrm{I} 897$ it exceeded IS millions. Austria-Hungary came next with I4 millions, and the United States third with Io $\frac{1}{2}$ millions. With regard to France, the state of things is ambiguous. The census of I906 showed an actual increase in the agricultural population of some 600,000 over that of I90r, and an advance from 4 r.S per cent. to 42.7 per cent. of the whole. But this seems to be due rather to a more careful enumeration than to any real movement, though some of the towns underwent an appreciable decline in this period. In any case the transfer from agriculture to industry and from country to town is proceeding very slowly in France, and the comparatively high and stable position of agriculture is remarkable. In Italy it has advanced both absolutely and relatively. Between I88I and Igor the agricultural population increased by over a million, and advanced from 56.7 per cent. to 59.4 per cent. of the whole. Finally we have Denmark, which presents such a striking contrast to all the rest that it is difficult to accept the figures 
without explanation. The case is unique at one end of the scale no less than that of England at the other cnd. Between ISgo and Igor the agricultural population more than doubled, and sprang from 27.I per cent. of the whole to 48.2 per cent. Some change in the method of enumeration is suggested by these results, but the statistical work from which all the above figures are taken-issued by no less an authority than the Imperial Statistical Office of Germany-makes no mention of any, although it expressly excludes the later but less complete census of Igo6 on the ground that it is not properly comparable. The inference is that in the opinion of this competent authority the censuses of I89o and Igor are valid for comparative purposes as they stand.

It should be understood that statistics of this kind must be read broadly. They will not bear being used for minute comparisons, because the census is not taken in a uniform manner in different countries, and allowance must be made for discrepancies on this account. A more exact enumeration might change the relative position of some countries which stand close together on the list; but the place of the United Kingdom, and still more of England at the bottom is separated from the rest by too wide an interval to be materially affected by any such qualification. 
Ireland, it should be added, comes fairly high up on the list when taken alone; the proportion of the agricultural population is 44.7 per cent. of the whole, which places it between Denmark and France.

\section{Density of Population.}

The foregoing statistics, with the qualification mentioned above, state in summary terms the actual position of agriculture as an occupation in the several States. But when inferences are drawn from them it becomes necessary to take other conditions into account. Like must be compared as far as possible with like. The proportion of the population living by agriculture is necessarily conditional, in the first place, by the extent of soil available in proportion to the inhabitants. A sparsely-populated land, such as Russia or the United States, offers opportunities which do not exist in a densely-populated one such as Belgium or England. The density must therefore be taken into account, and it is given accordingly in the second column of the foregoing table.

It will be seen that there is a certain amount of correspondence between density of population and the position of agriculture, though many discrepancies occur. Some of them are due to the fact that the total area, which is the basis of the calculation, contains 
far less land available for cultivation in some cases than in others. Norway and Sweden are the most conspicuous instances and form obvious exceptions. Three-fourths of Norway and one-third of Sweden are sterile. But it is equally evident that this does not account for other cases. The United States, for instance, make an extremely poor show. With a density only one-tenth that of Germany they occupy about the same place with regard to agriculture. Italy is an exception in the opposite direction. With the same density as Germany it has a far larger proportion of its population engaged in agriculture. The actual number is nearly the same in both-namely, a little short of ten millions. When the density of the population, which is about the mean, and the amount of mountainous land is taken into consideration, Italy's position is remarkable ; and, it must be remembered, the agricultural population is increasing there both relatively and absolutely. The conditions prevailing in Italy would evidently repay closer study.

\section{Countries of High Density.}

The countries at the bottom of the list, however, reveal a distinct correspondence between density and agriculture. They are the Netherlands, Belgium, the United Kingdom and its parts. All these are distinguished 


\section{BELGIUM AND NETHERLANDS 25}

by a higher density and a lower proportion of agricultural workers than any other State. It is accordingly with the Netherlands and Belgium that our own conditions can best be compared; and as it happens the former has almost the same density as Great Britain, while Belgium is only a little in advance of England and Wales; the two are approximately equal in regard to density and both are separated by a wide interval from all other units. A double comparison can thus be made on fairly level terms, and it brings out in a striking way the great difference between Continental and British conditions. In the one case the relative position of agriculture is as 30.7 to 9.3 and in the other as 2 I. I to 8.8. Nor can this be explained by differences in the area of land available for cultivation. The proportions are nearly the same in the Netherlands and in Great Britain; in both about one-third of the total area is not cultivated. In Belgium, on the other hand, the proportion excluded from cultivation is considerably larger than in England and Wales. Belgium has, therefore, a denser population for the whole area and a smaller proportion of land devoted to agriculture, and yet the agricultural population is as 2 I.I to 8.8 .

Another comparison may be made. There is one State in Europe which has a much 


\section{FOREIGN COUNTRIES}

higher population density than Belgium or England, and that is the kingdom of Saxony, with 320 inhabitants to the square kilometre. It is more highly industrialised and urbanised than even the Rhineland province of Prussia, and agriculture is reduced to a very inferior position. Yet even in Saxony it supports II.5 per cent. of the occupied population. Thus in a country more densely populated by one-third than England agriculture still maintains a position better by one-fourth. With these examples before us we cannot explain away England's unique position either by industrialisation or density of population. 


\section{CHAPTER IV}

\section{AGRICULTURAL PRODUCTION}

Between I790 and I799, says Porter, England ceased to be an exporting country for wheat. Up till then a good season still produced a superabundant supply for the needs of the population, and the excess was exported; in bad seasons the supply was deficient and had to be made good by imports. Thus of the ten years I780-90 six were years of exportation and four of importation. The change from an exporting to an importing country had been going on since I765, which Mr. Prothero selects as the turning point. From I7I5 to I765 the exports amounted to II $\frac{1}{4}$ million quarters, the imports only to 300,000 quarters. The change which set in after I765 was consummated in I792. Porter quaintly remarks that "this was the last occasion on which our farmers found relief in foreign markets for an over-abundant stock of grain." The price of wheat that year was 4IS. 9d. a quarter according to Porter, or 43s. according to Agricultural Statistics (Cd. 5786, I9Io). 
Either is exceptionally low for the period, when prices were leaping up towards the high-water mark of IIgs. 6d. which they reached in I8or.

\section{INCREASED PRODUCTION.}

In spite of high prices and the excessively rapid growth of the population, noted in a previous chapter, at the beginning of the rgth century importation remained very low and practically stationary for many years. That is to say, agricultural production still kept pace with the population, taking one year with another. The average number of quarters imported was:-I8OI-Io, 600,946; I 8 II-20, 458,578; I82I-30, 534,992; I83I-40, 907,638 . It follows that the home production must have increased rapidly during this period. Porter calculates that the number of persons fed on home-grown wheat, assuming a yearly consumption of eight bushels a head, rose from II millions in I8OI-IO to $I 6 \frac{1}{2}$ millions in I83I-40. The increased production implied by the rapid growth of population with practically stationary imports was only to a limited extent due to the employment of more labour in agriculture, because, as we have seen in a previous chapter, the number of agricultural families fell after I82I. Porter attributes it mainly to improved farming. 
"The increased production which is thus seen to have been brought about by a comparatively small addition of labour has in a great degree resulted from the employment of capital in improving the soil, in draining and manuring, in throwing down a great part of the fences with which our forefathers were accustomed to divide their farms into small patches; through the use of improved implements of husbandry, and, above all, through the employment of a better system of cropping by rotation."

$\mathrm{He}$ also mentions the assistance given to agriculture by science in the researches of Davy, undertaken at the instance of the Board of Agriculture about the beginning of the century, and those of Liebig later. But it must not be forgotten that between I80o and I820 over three million acres had been added to the cultivated area through inclosure; many persons suffered among the peasantry and small holders, but the people were fed. After I820 the process slackened, and in the next 30 years the total increase was only about one million acres.

Porter had no doubt that agricultural production would continue to increase indefinitely and keep pace with the needs of the population. He could not, in fact, conceive of a nation dependent for its food on other countries. Writing in $\mathrm{I} 846$ about the growth 


\section{AGRICULTURAL PRODUCTION}

of population and the concurrent increase of production, he says :

"The extent to which our progress has been carried is strikingly seen in continually increasing harvests, raised for provisioning the people, and which are the result of progressive applications of capital to the land. Great as has been the effect thus produced, there is reason for believing that we shall see far greater results from the same cause in future years. When our agriculturists shall have been made to feel that their chief dependence for prosperity must be upon their own skill and industry they will find that, like their fellow-subjects employed in trading and manufacturing pursuits, they too are able successfully to compete with those engaged in the same pursuit with themselves in other lands."

Here speaks the enthusiastic Free-trader. But, while the words were yet in his mouth, already the turn was being taken which was to falsify his optimistic forecast. It is necessary to recall all this because it shows that agriculture did not, as is commonly supposed, succumb suddenly or rapidly under the march of industrialism, which was proceeding at the maximum of intensity during the period under review. For many decades it advanced in productivity sufficiently to fulfil in a fair measure the function of feeding the popula- 
tion. And it did so through alternate periods of prosperity and adversity. From I 7 So to ISI3 agriculture was prosperous, though the poor suffered from high prices; from I8I4 to 1836 it was extremely depressed. Mr. Prothero attributes the prosperity of the first period mainly to the weather and the war, which sent up prices; after the war taxation and the fall of prices brought adversity. Each in turn seems to have stimulated effortprosperity by the hope of gain, adversity by the pressure of necessity. After I 836 agriculture began to look up again, and in 1852 entered on another golden age, which lasted in full for ten years and did not finally disappear in the gloom of a long and deep depression until 1874 . It was a time of great activity, in which mechanical invention, having developed urban industries, extended its influence to agriculture in the form of steam transport and farming implements. The improvements noted by Porter were extended; high farming, which was still the exception when he wrote, became general.

\section{Deficient Production.}

In view of all this, Porter's expectation that production would continue to increase and keep pace with the population is intelligible and not unreasonable; but what happened was the reverse. Home production became 


\section{AGRICULTURAL PRODUCTION}

more and more inadequate, and imports grew steadily and rapidly. We have seen above that the average annual imports of wheat rose to 907,638 quarters in $I 83 I-40$. This was due mainly to four bad harvests, for in 1836 the amount was only 25,000 quarters; but the tendency was upwards all the time. In 184 I-49 the annual average rose to $2,588,706$ quarters. Again there were several deficient harvests, but in good or bad seasons alike the deficit was rising. There was great distress, and in $x \& 46$ the sliding scale of import duties then in force under the Corn Laws was modified, with eventual abolition in 1849 . These laws, which dated from the Middle Ages and had undergone innumerable modifications, were, and still are, the subject of a vast amount of discussion. In Mr. Prothero's judgment they had little effect on prices, at any rate down to I8I5, and he thinks it almost impossible to decide whether their total effect was to promote or retard agricultural progress. "From I689 to I8I5," he says, " it is probable that the marked deficiency or abundance of the harvest in any single year produced a greater effect on prices than was produced by the Corn Laws in the I25 years of their existence as a complete system." This experience only conforms to the general truth that laws have a trifling influence compared with the 
large forces which really govern the conditions of life-a truth always forgotten or ignored by advocates of legislation. Laws can regulate action and encourage or discourage effort but they can neither initiate nor suppress it. On the natural conditions within which effort must operate and by which it is absolutely limited they have no influence whatever.

The abolition of the Corn Laws undoubtedly encouraged imports and discouraged home production through the great fall of prices which eventually followed; but the effective causes were the improvement of transport and the opening up of vast corn lands in America which Porter did not foresee.

\section{GROWTH OF IMPORTS.}

The following table, compiled from the returns of the Board of Agriculture, gives the imports of foodstuffs more comprehensively :

\section{Imports in Milizon Cwts.}

\begin{tabular}{|c|c|c|c|c|c|}
\hline Years. & & $\begin{array}{l}\text { Wheat } \\
\text { and } \\
\text { Flour. }\end{array}$ & Meat. & $\begin{array}{c}\text { Butter } \\
\text { and } \\
\text { Cheese. }\end{array}$ & $\begin{array}{l}\text { Eggs } \\
\text { in } \\
\text { millions. }\end{array}$ \\
\hline $186 I-65$ & $\ldots$ & 34.6 & 1.5 & I. 8 & 280 \\
\hline I 866-70 & .. & 37.2 & I. I & 2.0 & 418 \\
\hline $1871-75$ & .. & 50.4 & $3 . I$ & 2.7 & 602 \\
\hline $1876-80$ & .. & $63 \cdot 3$ & 5.8 & 3.6 & 760 \\
\hline $188 I-85$ & .. & 77.2 & 6.0 & $4 . I$ & 901 \\
\hline $1886-90$ & $\ldots$ & $77 \cdot 7$ & 7.6 & 4.7 & 1,123 \\
\hline I 89 I -95 & $\ldots$ & 96.5 & 10.4 & 5.7 & I, 377 \\
\hline $1896-1900$ & $\ldots$ & 95.9 & I 5.7 & 6.6 & I,794 \\
\hline $1901-05$ & .. & 111.6 & $17 \cdot 3$ & $7 \cdot 5$ & 2,271 \\
\hline $1906-10$ & $\ldots$ & I I 3.9 & I 8.8 & 7.6 & 2,200 \\
\hline
\end{tabular}




\section{AGRICULTURAL PRODUCTION}

The following table is taken from Mr. F. W. Hirst's new edition of The Progress of the Nation (I9r2). It shows the rapid and almost continuous rise of imports of grain, butter, and beef after 1849

Imports in Million Cwts.: Annual Average.

\begin{tabular}{|c|c|c|c|c|c|c|}
\hline \multicolumn{2}{|l|}{ Years. } & Wheat. & Barley. & Oats. & Butter. & Beef. \\
\hline I $85 I-55$ & $\cdots$ & 14 & 2.3 & 2.9 & 0.4 & 0.17 \\
\hline $1856-60$ & .. & 18 & 5.7 & 4.8 & 0.5 & 0.2 \\
\hline I 86 I -65 & .. & 28 & 6.3 & 5.9 & 1.05 & 0.24 \\
\hline I 866-70 & .. & 32 & $7 \cdot 4$ & 9.0 & I. 2 & 0.24 \\
\hline I $871-75$ & .. & 44 & I I.O & 11.6 & I. 4 & 0.25 \\
\hline $1876-80$ & $\cdots$ & 53 & 12.0 & I 3.0 & 1.9 & 0.73 \\
\hline I $88 \mathrm{I}-85$ & $\ldots$ & 58 & 12.0 & 16.3 & 2.4 & I. .02 \\
\hline $1886-90$ & $\ldots$ & 56 & 16.6 & I 5.1 & I. 8 & I. I4 \\
\hline I $891-95$ & .. & 69 & 21.8 & 15.4 & 2.4 & 2.02 \\
\hline I $896-1900$ & . & 67 & 20.1 & 17.0 & $3 \cdot 2$ & $3 \cdot 3$ \\
\hline $1901-05$ & .. & 87 & 24.8 & 17.2 & 4.0 & $4 \cdot \hat{3}$ \\
\hline I $906-08$ & . & 94 & 19.2 & 13.3 & 4.2 & 5.6 \\
\hline
\end{tabular}

During the period covered by the first table the population of the United Kingdom increased by 65 per cent. and that of England and Wales by roo per cent., while the imports of wheat increased by $47 \mathrm{I}$ per cent., of butter by 1,000 per cent., and of beef by 3,300 per cent. During the period covered by the second table the increase of population was only 56 per cent. in the United Kingdom and 80 per cent. in England and Wales, while the imports of foodstuffs rose at the rate of 400 per cent. to I,200 per cent. This immense and disproportionate rise of foreign produce 


\section{RISE OF IMPORTS}

is due in part to increased consumption per head accompanying a general rise in the standard of living, and is in itself positive evidence of the great improvement in the economic condition of the mass of the people. But it also connotes a failing production of these commodities at home.

Diminished Area of Crops.

The following table shows the crop distribution of cultivated land in England and Wales since IS66 :- 


\section{AGRICULTURAL PRODUCTION}

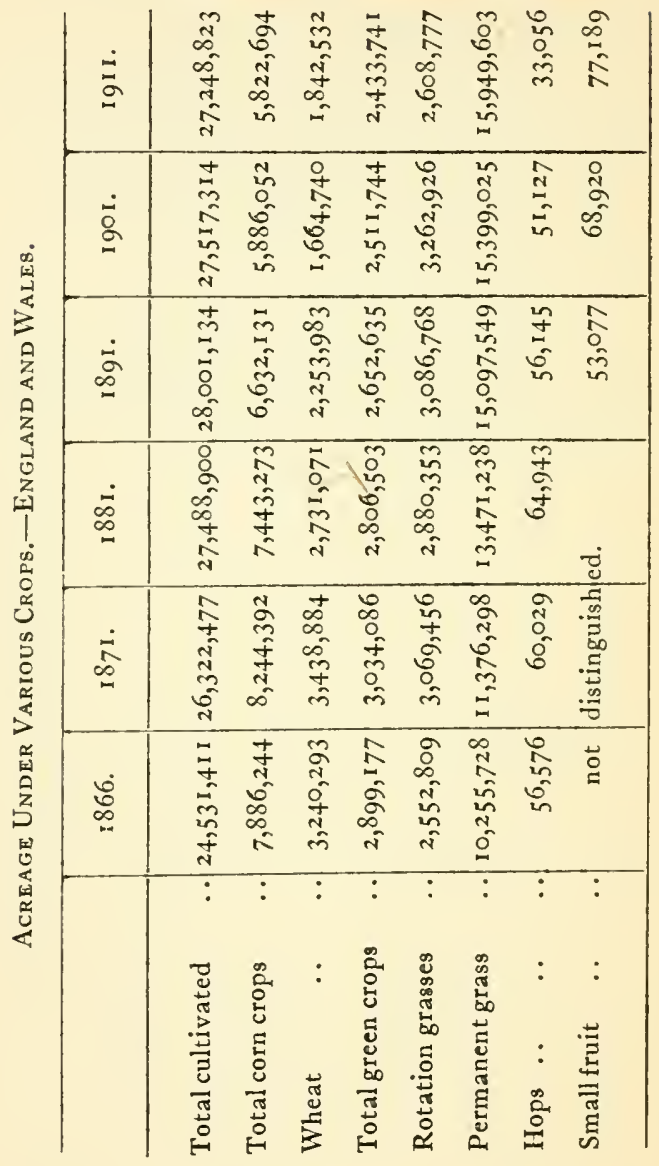


This table brings out the following points : (I) The total area under cultivation increased down to I89I by $3 \frac{1}{2}$ million acres, but it has since diminished by $\frac{3}{4}$ million acres. (2) The area under corn crops has been shrinking continuously since IS7I to the extent of $2 \frac{1}{2}$ million acres. (3) Wheat is the principal item in this change ; between I87I and I9or it fell $I \frac{3}{4}$ million acres, or more than 50 per cent. Between I9oI and IgI I small recovery took place, which was, however, more than counterbalanced by the progressive decline of barley. This crop is not given separately in the table, but it declined by about $\frac{3}{4}$ million acres, or one-third of the whole, between I88I and IgII. Oats, on the other hand, have not fallen since IS $7 \mathrm{I}$, but have slowly increased from about $\mathrm{I}_{\frac{3}{4}}$ million to 2 million acres. (4) Green crops, which means roots and vegetables, have also declined continuously since I87I to the total extent of 600,345 acres, or about 20 per cent. (5) The total decrease of arable land, made up of corn and green crops and fallow, since I87 I was over 3 million acres. (6) Grassland, including pasture and meadow but not heath and mountain grazings, increased continuously from $10 \frac{1}{4}$ million acres in I866 to I6 million acres in I9II, or 55.5 per cent. 


\section{PRICES.}

The reduction of arable land, and of the wheat-growing area in particular, which set in between I87I and I88I was accompanied by a fall in prices. The following table gives the average annual prices of wheat for each quinquennium from I866 to I9ro:

Average Prices of Wheat per Quarter.

\begin{tabular}{|c|c|c|c|c|c|c|}
\hline \multicolumn{3}{|c|}{ Years. } & Price. & \multicolumn{2}{|l|}{ Years. } & Price. \\
\hline $\begin{array}{l}\text { I } 866-70 \\
\text { I } 871-75 \\
\text { I } 876-80 \\
\text { I } 88 \text { I- } 85\end{array}$ & & $\begin{array}{c}\cdots \\
\cdots \\
\cdots \\
0 \\
06\end{array}$ & $\begin{array}{rr}\text { s. } & \text { d. } \\
5+ & 5 \\
54 & 6 \\
47 & 5 \\
40 & 1\end{array}$ & $\begin{array}{l}\text { I } 886-90 \\
\text { I } 89 \text { I-95 } \\
\text { I } 896-1900 \\
\text { I90 I-05 } \\
\text { 3 Is. I Id. }\end{array}$ & $\begin{array}{l}\ldots \\
\cdots \\
\cdots\end{array}$ & $\begin{array}{lr}\text { s. } & \text { d. } \\
3 \text { I } & 5 \\
27 & 6 \\
28 & 7 \\
27 & \text { II }\end{array}$ \\
\hline
\end{tabular}

In I869 the last vestige of the Corn Laws in the shape of the Is. duty, which had been in force since 1849 , disappeared ; but it cannot be shown that this exercised much or any influence in lowering prices. In I 869 the price was $48 \mathrm{~s} .2 \mathrm{~d}$. and in the next year it fell to 46 s. IId., but after that it rose during the next four years, mainly through the increased demand which followed the Franco-German war and the unparalleled industrial prosperity. After 1874 it fell again progressively and almost continuously until it reached the low-water mark of 22s. Iod. in I894. After this a process of recovery, not steady but distinct, set in. The fall in prices unquestionably produced the reduction in this crop, 
which began to increase again when the upward tendency of prices was sufficiently established to give farmers confidence.

Thus the decline of cereals is clearly connected with the growth of imports, through the effect of the latter on prices. But the imports themselves are the result of agricultural expansion in foreign countries, at first in Europe, afterwards in the United States, but more recently in Canada, Australia, and other British possessions. What has happened is that the world has supplied us more and more with cheap food at the expense of home agriculture; but while we became less and less self-supporting during the second half of the last century a change has now set in, and the Empire, though not Great Britain, is becoming more self-supporting. The imports of wheat and flour from foreign countries fell, in round figures, from 85 million cwts. in 1907 to 67 million cwts. in IgII, while those from British lands rose from 43 to $5 \$$ million cwts. The following official statement of the proportions of wheat and flour supplied for consumption in the United Kingdom in I9I2 from the three sources was recently given in the House of Commons: Home grown, 20.I per cent.; Colonial-grown 42.3 per cent.; foreign-grown, 37.6 per cent. 


\section{A Comparison.}

It remains none the less true that we might produce more and become more self-supporting at home. The following summary comparison is taken from a table in $\mathrm{Mr}$. Rowntree's study of Land and Labour in Belgium :

Net Balance of Imports and Exports Per Head of Population.

Annual Averages for 1901-05.

\begin{tabular}{|c|c|c|c|c|c|}
\hline \multicolumn{4}{|c|}{ Country. } & Imports. & Exports. \\
\hline United K & dom & & & $\begin{array}{ll}\text { s. } & \text { d. } \\
78 & 4\end{array}$ & s. d. \\
\hline Belgium & .. & .. & . & 455 & - \\
\hline France.. & . & .. & .. & 40 & - \\
\hline Germany & .. & .. & .. & I 7 I I & - \\
\hline Denmark & .. & .. & .. & - & $73 \quad 1$ \\
\hline
\end{tabular}

This well shows the unique position of the United Kingdom at one end of the scale and of Denmark at the other. Denmark makes out of surplus agricultural produce nearly as much as we pay for our deficit. The fairest comparison is with Belgium. A highly industrialised country with a denser population it comes nearer to supplying its own needs by $33 \mathrm{~s}$. a head or 42 per cent. If the comparison could be made with England and Wales the difference in favour of Belgium would be far greater. 


\section{INTERNATIONAL PRODUCTION 4I}

\section{Agriculture in Relation to \\ Population.}

The following figures are taken from the statistical returns issued by the Board of Agriculture. The first table shows the number of acres devoted to grain crops and potatoes and the second the number of cattle, sheep, and pigs per I,00o inhabitants in the countries enumerated:

ACres per i,OOO of Population.

\begin{tabular}{|c|c|c|c|c|c|c|}
\hline Country. & Wheat. & Barley. & Oats. & Rye. & Maize. & $\begin{array}{l}\text { Pota- } \\
\text { toes. }\end{array}$ \\
\hline Austria & 105 & 95 & 162 & 175 & 26 & 109 \\
\hline Belgium ... & 50 & I I & 8 I & $8+$ & 一 & 63 \\
\hline Denmark .. & 38 & 219 & 377 & $25^{8}$ & 一 & $5^{1}$ \\
\hline France .. & 395 & 48 & 252 & 73 & 26 & 97 \\
\hline Germany .. & 75 & 60 & 165 & 233 & - & I 26 \\
\hline Hungary .. & +38 & I 39 & 139 & $1+0$ & $3+0$ & $8_{3}$ \\
\hline Italy & 338 & is & 37 & 9 & I 17 & $2 I$ \\
\hline Netherlands & 24 & 12 & 57 & 94 & - & 69 \\
\hline Norway .. & 5 & 38 & 113 & 16 & - & 44 \\
\hline Sweden & 44 & 82 & 354 & 180 & $\longrightarrow$ & 68 \\
\hline U. States .. & 528 & 592 & 77 & 23 & I, I 28 & 39 \\
\hline U. Kingdom & 43 & 39 & 90 & & & 26 \\
\hline
\end{tabular}

The countries which compare most closely with the United Kingdom are Belgium and the Netherlands. The latter devotes less acreage to wheat, barley, and oats, and Belgium less to barley and oats, though more to wheat; but both grow rye in addition and are markedly superior in potatoes. It was 


\section{AGRICULTURAL PRODUCTION}

publicly stated the other day as a consoling fact that the yield of wheat per acre is still higher in the United Kingdom than anywhere else; but that is not borne out by the following official figures :-

Mean Yield per Acre in Bushels.

\begin{tabular}{ll|l|c|c|c}
\hline & & Wheat. & Barley. & Oats. \\
\cline { 1 - 1 } United Kingdom & $\ldots$ & 32.8 & 35.0 & 43.1 \\
Belgium & $\ldots$ & $\ldots$ & 36.2 & 49.2 & 57.2 \\
Netherlands &. &. & 34.4 & 47.5 & 54.2 \\
\hline
\end{tabular}

Nor is the poor show made by the United Kingdom in these crops offset by superior production of animals except in regard to sheep.

Number per i,ooo of Population.

\begin{tabular}{|c|c|c|c|c|}
\hline \multicolumn{2}{|c|}{ Country. } & Cattle. & Sheep. & Pigs. \\
\hline Austria & . & 321 & 85 & 225 \\
\hline Belgium & .. & $2+3$ & & 182 \\
\hline Denmark & .. & 834 & 269 & 543 \\
\hline France.. & .. & 367 & 415 & 170 \\
\hline Germany & . & 333 & 124 & 357 \\
\hline Hungary & . & $35^{\circ}$ & 409 & 363 \\
\hline Italy $\therefore$ & .. & 182 & 327 & 73 \\
\hline Netherlands . & .. & 341 & 150 & 212 \\
\hline Norway . & & 469 & 598 & 137 \\
\hline Sweden & . & 498 & 182 & 173 \\
\hline United States & & 645 & 572 & 700 \\
\hline United Kingdo & om & 261 & 672 & 94 \\
\hline
\end{tabular}




\section{CHAPTER V \\ LABOURERS' WAGES}

THE question of wages is important from several points of view. What part have they played in the process of rural depopulation? Have agricultural wage-earners suffered with farmers and landowners from the decline of the industry set out in the previous chapter? Can wages be raised and how? What would be the effect of raising them on agriculture? Would it facilitate housing? These and other questions arise in connection with wages; but they are very difficult to answer, and such answers as can be given are quite as likely to mislead as to inform. The economic condition of agricultural workers is an intricate subject for investigation. In most industries a statement of wages or earnings, with due regard to the cost of living, covers the ground sufficiently to permit of broad conclusions ; and valid data are obtainable which can be generally applied with no great qualification. But in agricultural life it is not so. The nature of the work varies so much, the conditions are so different in different parts of the country, and domestic economy is made up of so many items that general statements about wages may be merely misleading. For instance, the practice of boarding unmarried 
men, which does not obtain in other industries, tends to pull the average wage down, while the superior services of men engaged in the care of animals tend to pull it up ; and since these classes are not only employed in widely varying proportions in different parts of the country, but also change their proportions with changes in farming, summary statements must be used with caution. Then, again, the great variation in regard to aHowances in kind or subsidiary sources of income introduces another qualifying element of great complexity and uncertain value. In the recent official statistics account is taken of the more important of these disturbing factors, but in the use made of the statistics they are commonly ignored.

\section{The Course of Wages.}

The most comprehensive statement of wages available is that given by Mr. Prothero in English Farming Past and Present. It is compiled from a number of sources varying in value, and does not profess to do more than put together the material available. Mr. Prothero says in a note: "The actual value, in individual cases, of the returns of wages is doubtful ; but they probably represent some general approximation of the truth." The following table is condensed from Mr. Prothero's, but it is to be noticed that these 
figures are for cash wages only and for ordinary labourers. They do not include payments for piecework, cottages and gardens free or at rents below the letting value, harvest earnings, overtime money, or any extra allowances; and they do not apply to men having the charge of animals :

Average Weekiy Wages of Ordinary Agricultural Labourers.

\begin{tabular}{|c|c|c|c|c|c|}
\hline Year. & & $\begin{array}{l}\text { E. \& N.E. } \\
\text { Counties. }\end{array}$ & $\begin{array}{l}\text { S. E. and } \\
\text { E. Mid. } \\
\text { Counties. }\end{array}$ & $\begin{array}{l}\text { W. Mid. } \\
\text { and S.W. } \\
\text { Counties. }\end{array}$ & $\begin{array}{l}\text { N. and } \\
\text { N.W. } \\
\text { Counties. }\end{array}$ \\
\hline $1768-70$ & & $\begin{array}{cc}\text { s. } & \text { d. } \\
7 & 6\end{array}$ & $\begin{array}{c}\text { s. d. } \\
7 \text { I I }\end{array}$ & s. $\begin{array}{c}\text { d. } \\
6 \\
10\end{array}$ & $\begin{array}{ll}\text { s. } & \text { d. } \\
6 & 4\end{array}$ \\
\hline I 827 & .. & 95 & 98 & 82 & I I 4 \\
\hline 1837 & .. & 104 & 100 & 810 & I 2 \\
\hline $1 \$ 50-1$ & & 9 I & 9 & 72 & I I 10 \\
\hline 1860 & . & I I I & I I 9 & 9 I I & 135 \\
\hline I $869-70$ & & I I 3 & 125 & 1010 & 150 \\
\hline 1872 & . & 132 & $\mathrm{I}_{4} 10$ & 13 I & $17+$ \\
\hline 1882 & . & 130 & $14 \quad 1$ & 1210 & 169 \\
\hline 1892 & . & 127 & 130 & II 10 & 165 \\
\hline 1898 & . & $12 S$ & 1310 & 12 I I & I 6 I I \\
\hline 1910 & $\ldots$ & 140 & $15 \quad 1$ & 139 & 180 \\
\hline
\end{tabular}

The returns for the earlier years given in the table are mostly from private sources and rest on no uniform method of inquiry. Those for I768-70 are taken from Arthur Young's Tours; those for $\mathrm{I} 824$ from an abstract, which Mr. Prothero calls "very defective and unreliable," prepared for the Select Committee on Labourers' Wages of I825, which shows, by the way, how long ago the subject engaged the attention of Parliament; those 
for 1837 from Purdy's statistics; and those for I850-I from Sir James Caird's English Agriculture. The striking drop shown by the last-mentioned suggests a different basis of calculation. From I860 onwards the figures are from official returns, and since this is the period which has chiefly been dealt with in previous articles attention may be confined to them. They exhibit a general rising tendency up to $I 872$, then a fall to $I 892$, followed by a larger rise. The movement thus shown is broadly confirmed by the following summary but more continuous figures given by Mr. Hirst in the Progress of the Nation (IgI2) :Average WeEkLy Wages.

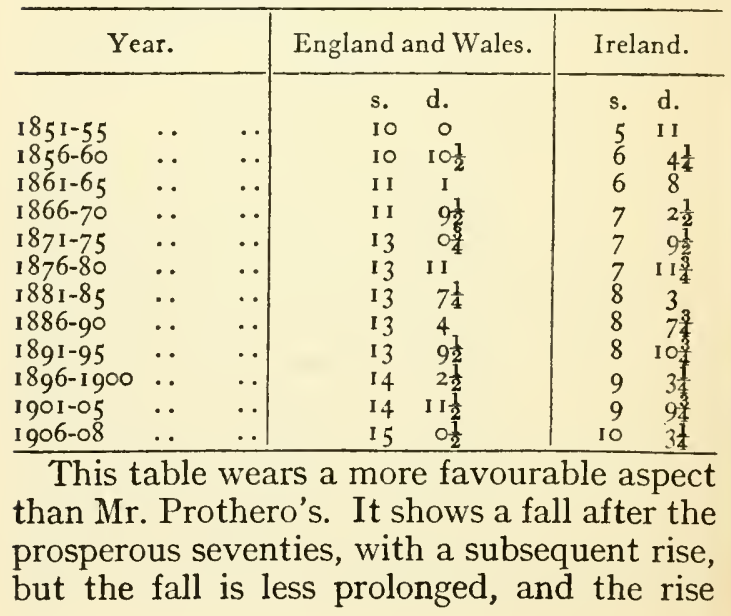


begins earlier. In Ireland wages have risen progressively throughout the whole period. The conclusions suggested by the survey are, first, that the movement of wages in no way accounts for rural depopulation, which has gone on most rapidly when wages were rising -namely, in I86I-7I, in I89I-I9oI, and more recently. Attention has been drawn to this fact in a previous chapter, but its repetition is in place here. The second conclusion is that the condition of agricultural labourers has substantially improved during the last halfcentury. In I866-70 the average wage was IIs. $9 \frac{1}{2} \mathrm{~d}$., the price of wheat $54 \mathrm{~s} .5 \mathrm{~d}$. a quarter, and that of beef at the Metropolitan Cattle Market $5 \frac{1}{4} \mathrm{~d}$. to $8 \mathrm{~d}$. a lb. In I906-Io the average wage was $15 \mathrm{~s}$. $0 \frac{1}{2} \mathrm{~d}$., the price of wheat 3Is. IId. a quarter, and of beef $4 \frac{1}{8} \mathrm{~d}$. to $7 \frac{1}{4} \mathrm{~d}$. per lb. The figures are worth tabulating :

\begin{tabular}{|c|c|c|c|c|}
\hline Year. & & $\begin{array}{c}\text { Average. } \\
\text { Wage. }\end{array}$ & $\begin{array}{l}\text { Price of } \\
\text { Wheat. }\end{array}$ & $\begin{array}{c}\text { Price of } \\
\text { Beef. }\end{array}$ \\
\hline $\begin{array}{ll}1866-70 & \ldots \\
1906-10 & \ldots\end{array}$ & & $\begin{array}{l}\text { I1s. } 9 \frac{1}{2} \mathrm{~d} \text {. } \\
\text { I5s. } 0 \frac{1}{2} \mathrm{~d} \text {. }\end{array}$ & $\begin{array}{l}54 \text { s. } 5 \mathrm{~d} \text {. } \\
3 \text { Is. I Id. }\end{array}$ & $\begin{array}{l}5 \frac{1}{4} \mathrm{~d} \text {. to } 8 \mathrm{~d} \text {. } \\
4 \frac{1}{8} \mathrm{~d} \text {. to } 7 \frac{1}{4} \mathrm{~d} \text {. }\end{array}$ \\
\hline
\end{tabular}

Present Rates of Wages.

The upward tendency of wages shown above has continued. The figures previously given relate only to cash wages, as already explained. When the various allowances are taken into account the actual receipts are sub- 
stantially raised. The Board of Trade inquiry in I907 included both and brought out the rates given in the table below. We place beside them the results of a subsequent inquiry made on the same plan in I9r2-r3 by the Rural Labourers' League :-

Average Earnings of Ordinary Agricultural LABOURERS IN ENGLAND.

\begin{tabular}{|c|c|c|c|c|}
\hline \multirow{2}{*}{ Division. } & \multicolumn{2}{|c|}{$\begin{array}{c}\text { Board of Trade } \\
1907 .\end{array}$} & \multicolumn{2}{|c|}{$\begin{array}{c}\text { Rural League, } \\
\text { I91 } 2-13 .\end{array}$} \\
\hline & Cash. & Total. & Cash. & Total. \\
\hline Northern Counties & s. d. & s. d. & $\begin{array}{ll}\text { s. d. } \\
\text { 2I }\end{array}$ & s. d. \\
\hline Yorkshire, Lanca- & & & & \\
\hline shire, Cheshire. . & 167 & 196 & I 80 & 209 \\
\hline N. and W. Midland & I5 3 & 183 & 165 & 192 \\
\hline $\begin{array}{l}\text { S. Midland and } \\
\text { Eastern ... }\end{array}$ & 13 & 16 & I4 I I & I 7 \\
\hline S. Eastern $\ldots$ & $\begin{array}{ll}5 & 5 \\
15 & 4\end{array}$ & 181 & 163 & I8 4 \\
\hline S. Western & 136 & 1610 & 148 & I7 9 \\
\hline Mean of Divisions & I4 4 & 17 II & 1610 & I9 4 \\
\hline
\end{tabular}

Statistics have also been recently published by the Central Land Association and the National Home and Land League. The figures of the former are somewhat higher than those of the Rural Labourers' League ; those of the National Home and Land League are almost identical with those of the Board of Trade for I907. With regard to the table given above it must be remembered that in 
particular counties the rates are lower and also higher than the averages. For instance, in Oxfordshire the rate is I4s. IId.; in Norfolk, I5s. 4d.; and in Suffolk, I5s. 9d. in the Board of Trade's return. On the other hand, the figure for Derbyshire is 20s. $5 \mathrm{~d}$. ; for Middlesex, 20s. 3d. ; and for the West Riding 20s. It must also be remembered that all these are averages, and that individual labourers earn both less and more. Wages are noticeably high in the principal mining counties, namely-Durham, Derbyshire, Northumberland, Lancashire, the West Riding of Yorkshire, Glamorganshire in Wales, and Lanarkshire in Scotland. This has suggested the explanation that the local competition of mining and other industries is the cause of the higher rates. But it by no means accounts for all cases, and another factor deserving of attention is the relative proportions of arable and pasture land. Where the latter predominates the wages paid per man are higher, but fewer are employed and the wages paid per acre are lower. This has an important bearing on the question of raising wages, to which reference is made further on. In all parts the wages paid to men in charge of animals are higher than those in the table, which refer to the lowestpaid class of permanently-employed men. 
Owners, Farmers, and Labourers.

Of the three classes affected by the decline of agriculture dealt with in previous chapters -landowners, farmers, and labourers-the last have emerged in the best condition, the first in the worst. Upon this Mr. Hirst and Mr. Prothero are agreed. Speaking of the great fall in prices and the prolonged depression which set in after I874, Mr. Hirst observes:

" The difficulty of meeting foreign competition had fallen heavily on both tenants and owners of land. The smaller owner suffered most of all because . . he had no hope of meeting his losses either by a saving of rent or out of his private means. . . . But in cases where the owner was not the cultivator the farmer was to some extent assisted by securing a reduction in rent. . . The natural tendency has been more and more to shift the burden from the occupier back on to the owner of the soil."

The figures compiled by Mr. R. J. Thompson show that rents rose in the prosperous period from I85I to the later seventies. Wages were rising then, too; prices were high and profits good. All three classes shared in the prosperity. But when the tide turned, rents went down rapidly. The following table gives Mr. Thompson's figures, which are, unfortunately, only brought down to I 896 : 
Average Rent per Acre: England and Wales.

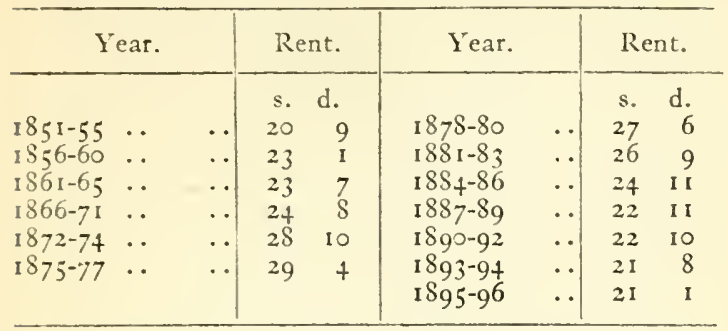

This table shows the upward and the downward movement in parallel columns. The falling column displays the reductions of rent which came to the relief of farmers on the side of the owner. The fall in wages given above represents the relief sought by him on the side of the labourer. The latter shared in the general depression, and, as Mr. Prothero observes, though the labourers suffered least in actual money loss, "standing as they do, nearer the border-line of starvation, it is probably true that they also suffered most." But, as we have seen, they have subsequently far more than regained their position. Farmers also, says Mr. Prothero, have improved theirs; "for landlords alone, although agricultural land readily commands both tenants and purchasers, the general conditions have materially changed for the worse." The annual value of land in Great Britain, according to the income-tax 
returns, fell by over Io $\frac{1}{2}$ millions sterling between 1875 and I894; and in the same period the capital value of land is stated to have fallen from 30 to about I8 years' purchase of annual value. "On this basis, which is probably an extreme one, the capital value of land fell between 1875 and I894 from $£ 2,007,330,000$ to $£$ I,OII,829,2I2, a decrease of $£ 995,500,788$, or about 50 per cent." (Hirst). There is clearly a large process of change going on, and one feature of it is that land-ownership without cultivation has passed from being a great source of income and is tending to become an expensive hobby which only rich men can afford.

\section{Proposals to Raise Wages.}

It is not the object of this volume to criticise proposed measures of reform, except for the purpose of explaining them ; but two points in connection with wages, which have a bearing on the question of raising them by legislation where they are low, may be mentioned here. The first is that labourers have in the past rather been driven than drawn off the land in this country, as was shown in a previous chapter. In recent years that has changed, but the attraction is not so much higher wages as a wider outlook. Agricultural life offers no prospects to young men of spirit. 
The second point is the relation of wages to the kind of cultivation. The rate of wages paid per acre varies inversely with the rate paid per man. Thus the lowest individual wages are paid in the Eastern group of counties-Norfolk, Suffolk, Cambridgeshire, and Essex-where they range from $\mathrm{I}_{5} \mathrm{~s} .4 \mathrm{~d}$. to I6s. $4 \mathrm{~d}$. But in these counties the average wage per acre ranges from $£ I 7 \mathrm{~s}$. $6 \mathrm{~d}$. to $£ I$ I 4 S. If we take, on the other hand, the high-wage Northern group and Derbyshire, where individual wages are over I9s. or 20s., there we find the wage paid per acre is only from IIs. $7 \mathrm{~d}$. to I5s. $8 \mathrm{~d}$. That is to say, it is the former group, which are mainly arable, that maintain the largest agricultural population, put most money into the soil, and take most produce out. And it is these counties with which it is proposed to interfere for the purpose of bringing them up to the level of the others. The course of agriculture in this country and the standing facts all point to the probability that the process of levelling up these counties on the man wage will entail levelling them down to the others on the acre wage. 


\section{CHAPTER VI}

\section{HOUSING}

MucH attention has been directed in recent years to rural housing in connection with the land question, but the subject is obscured by failure to distinguish the housing of agricultural labourers from rural housing at large. The latter covers much wider ground and has a different object in view. The confusion lies in the word "rural," which is loosely used in a general sense as synonymous with " agricultural," and also in a technical administrative sense as opposed to " urban." In this sense it covers a great deal of ground which has nothing to do with agriculture or the land question. It includes colliery and mill villages, suburban districts, small market and shopping centres, and other places inhabited by non-agricultural classes. Rural housing, thus regarded, is part of the administrative problem of public health, and is both more extensive and more urgent than that part of it which is really concerned with agricultural life. The most insanitary conditions and the worst over-crowding occur in colliery villages, particularly in the North of England and Scotland, where traditional and obsolete forms of housing, such as rows of one-storey back-to-back cottages, prevail. 
The inclusion of these conditions puts the question of agricultural housing in a false light. But the confusion between two different objects is still more misleading. The primary concern of public health is to prevent people from living in insanitary conditions, and consequently it seeks to abolish them, even at the cost of abolishing the people as well. It begins by pulling down, and is much less concerned with the far more difficult task of building up, as the record of proceedings under the Housing Acts abundantly proves. Still less is it concerned with the occupation of the people who are the object of its care. It has nothing whatever to do with the prosperity or adversity of any particular industry, or indeed of industry in general. So long as people do not live in insanitary dwellings they may cease to live altogether, for all that the public health service cares about it. The medical officer and the surveyor say: "These cottages are unfit to live in-they must come down." What becomes of the people or of the industry that depends on them is not their affair. In fact, the ideal of public health is compatible with the total extinction of agriculture or any other industry.

But the land question is concerned primarily with the prosperity of agriculture, and from this point of view the only relevant 
point is the adequacy of housing for agricultural labourers and its bearing on agricultural depopulation. To drag in the overcrowding in mining villages and the reports of medical officers on entirely different sections of the population is to mix up another problem.

\section{Deficient Housing.}

It is something of a paradox that the large decline in the population to be housed, which has been discussed in previous chapters and is, in fact, the chief count in the whole case, should be accompanied by a deficiency of housing accommodation for the dwindling remnant. The explanation lies partly in the distribution of depopulation on the one hand and of deficient housing on the other. Both are spoken of in summary terms as though they applied everywhere alike, whereas their local distribution is very irregular and there is no correspondence between the two. Another reason is the neglect of housing during the periods of agricultural depression, when all avoidable expenditure was avoided, old houses were allowed to fall into dilapidation, and new ones were not built. But the chief reason is the rising standard of requirements from the social and the administrative point of view. The whole standpoint has changed, and conditions which once were thought of no importance and passed without 
notice are now the objects of close scrutiny and official regulation. This has worked in two ways, in the condemnation of old houses and in the discouragement of building new ones. Another condition tending to diminish the supply of cottages available in some districts is the occupation of existing ones by other classes such as townspeople on holiday, railwaymen, servants attached to country houses, golf caddies and ground men.

These considerations explain the deficiency in a general way, but they afford no guide to its extent. Nor is any precise information available on the subject, although attention was drawn to it nearly 30 years ago in the evidence given before the Housing Commission of $\mathrm{I}^{8} 8_{5}$, and since then various inquiries have been held. In I906 a circular inquiry produced the following replies from I99 districts: Accommodation inadequate, 56 ; adequate, III ; in excess, 32. A more comprehensive return was obtained in I9II by the National Land and Home League, which circularised all the rural district councils in England and Wales. Replies sufficiently complete to use were received from 289 councils in $3 I$ counties. Of these ISI reported a dearth of cottages and 107 the contrary. It appears from this that the state of things had certainly not improved between I906 and I9II. The proportion of districts with suffi- 
cient and insufficient cottages respectively varies widely in different parts of the country. The counties in which the largest proportion of councils reported a lack of cottages were Norfolk, with I5 cases of insufficiency to one of sufficiency, Devonshire with I2 cases to none, Suffolk with Io to none, Essex with 9 to $I$, and Lincolnshire with 7 to $I$. On the other hand, from Lancashire Io reported sufficiency against 2 insufficiency; in Durham the figures were 7 against 2 , in the West Riding of Yorkshire Io against 8, in Leicestershire 6 against I. Here we see again a broad tendency towards the same division that we noted in regard to wages-on the one side the predominantly arable counties with low wages, on the other the predominantly grass counties with high ones. The former suffer most from inadequate housing, and this is exactly what might be expected. The agricultural population is thicker in the arable counties, where more men are employed to the acre. Thus the number of acres to each man employed is 26 in Essex, 27 in Suffolk, and $3 I$ in Norfolk; whereas it is 60 in the West Riding, 67 in Derbyshire, 83 in Durham and 97 in Northumberland. In contemplating measures of reform having wages and housing for their objects, the possibility must be borne in mind that raising the former counties to the level of the latter in these 
matters may at the same time reduce them also to the level of the latter in regard to agricultural population and production.

\section{Housing and Depopulation.}

The Board of Agriculture's Report on the Decline in the Agricultural Population (I9o6) makes the following observations on the lack of adequate housing :-

"Among specific causes of discontent, a deficiency of adequate or satisfactory housing accommodation is reported from about 30 counties. The details where given may be referred to, but speaking generally, there is evidence not only-or perhaps it should be said, not so much-of an actual scarcity of cottages, though this is mentioned in some cases, as of a lack of cottages which satisfy the more exigent requirements of the labourers in these times or comply with the demands of vigilant sanitary authorities. As with every other class, the rural labourers' standard of comfort has been raised, and they are not now contented with the accommodation which previous generations placidly accepted.'

An analysis of the detailed reports shows that housing was returned as a contributory cause of depopulation from 27 out of $8 \mathrm{I}$ counties in Great Britain. Of course these reports are not exhaustive, and the state of 
things has, perhaps, since grown worse ; but it is clear that inadequate housing is by no means universal. Its incidence is partial, and nowhere is it put forward as the principal reason for agricultural decline. Where it does occur stress is laid on the quality. The complaint is that "good," "suitable," or " better" cottages are lacking, and attention is drawn to the advanced standard which is brought home to young villagers by the contrast with the superior accommodation of modern urban housing. But this is only one of many attractions offered by the town and much less in evidence than others. The conclusion is that, though inadequate housing is a factor contributing to the decline of agricultural life, it is only one, and not the most important. This does not mean that nothing should be done for it; but it does mean that housing alone will not do much to help agriculture, and that if it is made an object in itself to be pursued without regard to the real object or to other more influential factors it may do more harm than good. If, for instance, the interests of the industry are lost sight of and too great a burden is placed on it the result may be to increase depopulation. So, too, if the claims of public health are put too high and injudiciously enforced, sanitation may be established in rural districts on the same principle as order in Warsaw. 


\section{Measures of Reform.}

Something of this kind seems to have happened and to be happening. The chief effect of housing legislation on the countryside has hitherto been to check building by putting the requirements too high. Wealthy landowners have done a great deal to improve housing on well-kept estates, though it has been neglected on others. It is a pity that no comprehensive record exists of the amount of cottage building done by them ; it is probably much greater than is commonly supposed. But it would certainly have been more but for insistence on unnecessary and rigid requirements, which make the cost prohibitive to men of moderate means, as a great many landowners are now. That was recognised by the circular letter from the Local Government Board issued in August, I9I2, in which local authorities were urged to review the requirements of their by-laws, "so that, while prescribing reasonable provisions with a view to securing stability, protection from fire, and conditions essential to health, they should not be unduly restrictive in regard to the erection of small dwelling-houses." Cost has been prohibitive, not only to landowners, but also to public authorities, who were empowered to build under the Housing Act of 1890 . In the course of 15 years down to the end of 1905 the total 
sum of $£$ IO, 300 was lent to five rural district councils for this purpose. Since then down to the end of July, IgI2, loans to 25 councils to the total amount of $£ 95,646$ had been sanctioned. Out of this amount $£ 58,886$ belonged to the period subsequent to the passing of the Housing and Town Planning Act, which has been followed by a considerable increase of activity. But it is to be observed that the amount of housing thus accomplished is very much less than the amount of unhousing under the same Act. It appears from the returns that under the heading of houses closed or demolished a score was run up of 2,455 , while houses built or to be built only mustered 3I5. Public health has beaten agriculture badly. This is not all that has been done, because several thousand houses have been repaired and put in order; but a deficiency of cottages is not likely to be made good by pulling down eight times as many as are built.

\section{WAGES AND RENT.}

Hence recent proposals for fresh legislation. Two remedies are proposed, one of which is to raise agricultural wages, so that the labourer can pay more rent; the other is to provide further facilities for borrowing money for building. The whole difficulty is one of cost, which exceeds the return that a labourer can afford to pay in rent. If a landowner builds 
he loses money on it ; if a public body builds a charge falls on the rates; and both are naturally loth to incur the liability. But if the labourer could pay an economic rent the difficulty would disappear. This could only be made possible by raising his wages. In that case what of the farmer? There seems to be an opinion among agriculturists who are not farmers that the present improvement in their financial position, due to the rise in prices, enables them to pay higher wages; and in fact wages are being raised. But it is highly improbable that they can or will be raised where they are lowest sufficiently to pay the difference between a full and a reduced rent without some other adjustment. If that took the form of withdrawing other allowances the cottager would be worse off than before by just so much, which is not to be thought of. An alternative is to compensate the farmer by a corresponding reduction in his rent, for which the owner would be reimbursed by the full rent for his cottages. There would thus be a financial readjustment all round. It looks very simple, and Mr. Whetham has given an account of its successful introduction on a Devonshire estate; but since on many estates farm rents are already below the economic level one anomaly would only be cured by increasing another. 
Public Money for Building.

The second remedy, which is the advance of public money for building, has already been made the subject of several Bills in Parliament; but has unfortunately become a matter of party politics because of differences of opinion on the question whether such assistance should be given only to public bodies or also to individuals and private associations. Common-sense suggests that the test is the attainment of the object, and that if assistance is given at all it should be given to those agents who will make the best use of it, whether they are private or public. The choice will no doubt vary with local circumstances. In Ireland over 39,000 cottages had been built in all parts of the country down to March, I9I2, and between 7,000 and 8,000 more had been sanctioned under the Labourers Acts. The system there is that of advances made to rural district councils by the Public Works Commissioners and repayable in $68 \frac{1}{2}$ years. Uneconomic rents are charged, ranging from as low as $6 \mathrm{~d}$. in poor districts to 2s. 9d. in the neighbourhood of Dublin. Rents vary much in different parts ; they are highest in Ulster, where they are commonly about Is. 6d., and rather less in Connaught, which comes next; in Leinster they are most commonly about Is., and in Munster under Is. Although the cost of building is much lower 
than in England these rents entail a heavy charge on the rates, averaging $5 \mathrm{~d}$. in the pound. The example of Ireland is stimulating, but it is possible to improve upon it. There is nothing new in the principle, which has been in operation since I 846 . Under the Land Improvement Acts, $f_{\mathrm{I}}, 392, \mathrm{I} 78$ has been advanced for building cottages, and $£ 5,562,276$ for farm buildings.

In fine, the problem is to provide the housing needed in the most economical way, and no means should be ruled out on the ground of prejudice. Among the possibilities to be kept in view is the application of new methods of building suggested by science and invention. An instance may be mentioned in the method devised and practised with success by the Rev. J. M. Milner, of Padstow, in Cornwall. He is a scientific man, and by the application of scientific principles he has hit upon a system which saves not less than 25 per cent. of the cost, satisfies the local authority, and pleases the tenant. The possibilities of invention are inexhaustible and they have not infrequently changed the whole situation. 


\section{CHAPTER VII \\ SMALL HOLDINGS}

THE extension of small holdings has for many years been advocated as an effective means of checking agricultural decline. It has lately taken a foremost position among remedies, and discussion tends to concentrate more and more upon the methods of promoting it. A desirable preliminary is a clear idea of what is a small holding. The official definition is a holding of from one to 50 acres ; but something nearer five acres than 50 is usually implied by the term. It is commonly assumed that such holdings were once very numerous, but have recently diminished through changes in the methods of agriculture or other influences. This belief probably rests on the report of a Select Committee of the House of Commons on the subject in I890, "that there had been until quite recently a considerable diminution in small holdings, due to economic causes and especially to the policy of consolidating farms whch prevailed largely until the last few years." The Committee thought that this movement had 


\section{SIZE OF HOLDINGS}

practically ceased in ISgo, but it is extremely difficult to say what has really happened. A comparison of the size-distribution of holdings in $I S_{5} I$ taken from the Census with that of Igo8, as given in the Census of Production, presents the following curious result :

Percentage of Total Holdings in Great Britain.

\begin{tabular}{|c|c|c|c|c|}
\hline Year. & $\begin{array}{c}1-5 \\
\text { Acres. }\end{array}$ & $\begin{array}{l}5-50 \\
\text { Acres. }\end{array}$ & $\begin{array}{l}50-300 \\
\text { Acres. }\end{array}$ & $\begin{array}{c}\text { Above } \\
300 \text { Acres. }\end{array}$ \\
\hline $\begin{array}{l}1 \delta_{5} I \\
1908\end{array}$ & 6.7 & 53. & $3^{6.1}$ & 3.7 \\
\hline & $21 \cdot 3$ & 45. & 29.6 & 3.7 \\
\hline
\end{tabular}

The two sets of statistics are not properly comparable, because the enumeration in I S5 $_{5}$ was based on the number of farmers and farms, not of holdings, and several holdings were no doubt included in some farms. This would particularly affect the smaller-sized holdings and reduce their number. Nevertheless the figures show certain things. It is evident that by $185 \mathrm{I}$ quite small holdings had become very few, and that the predominance of the medium-sized farm had been fully established then. This was just anterior to the period-the last one-of marked prosperity for British agriculture; and the great changes which produced high farming, together with the previous ruinous 
depressions, had already driven out the small man. We have to go back a great deal further to find the time when he flourished. The figures also show that the tendency of changes since $185 \mathrm{I}$ has not been in the direction of increasing large farms. This is further shown by the more strictly comparable figures of the Board of Agriculture for I885, I895, and I905.

\section{GREAT BRITAIN.}

Number of Holdings.

\begin{tabular}{|c|c|c|c|c|c|}
\hline Year. & & $\begin{array}{c}\text { I-5 } \\
\text { Acres. }\end{array}$ & $\begin{array}{c}5-50 \\
\text { Acres. }\end{array}$ & $\begin{array}{l}50-300 \\
\text { Acres. }\end{array}$ & $\begin{array}{c}\text { Above } \\
300 \text { Acres. }\end{array}$ \\
\hline $\mathrm{I} \mathrm{S}_{5}$ & . & 1 35,736 & 232,955 & 144,288 & 19,364 \\
\hline 1895 & .. & 117,968 & 235,48 I & 147,870 & I 8,787 \\
\hline 1905 & .. & I 10,259 & 232,966 & 150,561 & 17,9 I 8 \\
\hline
\end{tabular}

The very small and the very large holdings both show a continuous decline, while the medium-sized farm has steadily increased at their expense, and the small farm has remained stationary after a fluctuation in I 895 . The decline in the smallest class was really less than is shown here, because in I 885 holdings of exactly one acre, which numbered about 16,000 , were included, but omitted in the later years. The distribution of the several classes varies widely in different parts of the country, and the movement indicated in the above table is by no means uniform. 


\section{THE ECONOMIC SIZE}

For instance, in the south-eastern counties both the smallest ( $\mathrm{I}-5$ acres) and the second (5-50 acres) class increased, the latter by some 2,000 , or I 3 per cent., between IS8 5 and I905; and a tendency to the continuous increase in this class is shown in two or three other divisions. But all divisions alike show a decrease of the largest class (over 300 acres) and an increase of the 50-300 class. In I9I 2 the last-named class represented 59.3 per cent. of the total acreage farmed in England and Wales.

\section{The Predominant Size.}

The marked tendency of farming to gravitate towards this class of holding can only be ascribed to its superior suitability under existing conditions. It is the survival of the fittest. The average size of the farms included in the class was I25 acres in I9I2, and some reasons for its predominance that suggest themselves are that a farm of this size can be economically worked with little labour and yet is large enough to withstand the vicissitudes of the seasons, which are apt to overwhelm the man who farms on a smaller scale. At the same time, it does not require too much capital. It is a pity that the official returns do not define some intermediate sizes between the wide limits of 5-50 and 50-300 acres, which would make it possible to get 
nearer to what may be called the economic standard farm in different parts of the country. Such a definition would be a valuable guide both to legislation and to voluntary efforts. The more nearly they conform to the standing economic conditions the more likely they are to succeed.

With regard to the classes below the predominant one in size, the $5-50$ class, which is technically included under " small holdings," is numerically by far the largest of all, though it occupies a much smaller acreage than the former-namely, I4.7 per cent. of the whole area, against 59.3 per cent. It evidently suits a very large number of farmers, and it has also quite recently been increasing. Between Igro and Igr2 the number of holdings rose from I98, I39 to 200,522 in England and Wales. These facts are encouraging; but what distinguishes this class from the other is the fluctuation in its numbers. While the 50-300 class has steadily increased in nearly every division, the 5-50 class has moved up and down, as though it had been taken up and then dropped again. That is also the case with the I-5 acre class. If the periods of rise and fall are examined the conclusion is suggested that the rises are due to legislation and discussion which have stimulated the establishment of holdings of this size both by local authorities and private enterprise, 
and that the subsequent falls are due to failure of the experiment in a considerable number of cases.

\section{Small Holdings Acts.}

Apart from allotments, for which legislation was passed in 1887 , the first Act for stimulating the growth of small holdings was passed in 1892 , after an inquiry and report by a Select Committee in I8go. The table given above shows an appreciable increase in the number of 5-50 acre holdings in IS95 over I $88_{5}$. But by I $_{905}$ the number had dropped back almost precisely to the 1885 level. The Act was pronounced a failure. In 1905 another inquiry was held by a Departmental Committee, and this was followed by another Act in I907, to be superseded by an amending and consolidating Act in Igo8, to which an addition was made in IgIo relating to compensation for compulsory purchase. It is since this legislation that the $\mathrm{I}-5$ acre and 5-50 acre holdings have exhibited an upward tendency. The year Igo8 was the low-water mark, after which a gradual rise set in, though the smaller class fell back again in I9I2. It is evident that these classes, which comprise the official small holdings, can be increased, under an artificial stimulus, but they require special conditions for success. The 5-50 class is the more successful of the two; it comes 
nearer the natural economic standard. The average size of holdings in this class is just about 20 acres, and it is an interesting coincidence that in Germany holdings of from 25 to I25 acres account for a far larger proportion of the total area than any other class.

Down to the end of IgII - that is, during four years after the passing of the Igo7 Actland had been provided for I2,529 applicants in England and Wales; but this does not mean that small holdings had increased by that number. Many of the applicants already had small holdings and merely added to them ; others fell out. The actual increase in the number of holdings under 50 acres between IgoS and IgI2 was 5,544. This is not a great number out of a total of about 435,000; but it shows some movement. The average size of the holdings acquired under the Acts was between I3 and I4 acres, which approximates towards the general average of the 5-50 class. It appears, therefore, that this size is more successful than the $I-5$ holding. And the demand is brisk; the county councils administering the Acts have been unable to keep pace with it. Nor is the movement confined to them: down to the end of IgI I private landowners had provided 2,644 applicants with land to the amount of over 32,000 acres, but these represent only the cases arranged " mainly through the 
instrumentality of the councils." The official report says that " the actual number so provided is probably considerably in excess of these figures." Of the whole number of applicants provided nearly 35 per cent. were described as agricultural labourers. The counties which have made most use of the Acts are Norfolk, Cambridge, Isle of Ely, Lincolnshire, Worcester, Somerset, and Huntingdon. The chief reasons for their prominence seem to be the lead given by energetic individuals who believe in the principle and the previous prevalence of small holdings in the same district.

\section{Conditions of Success.}

All this indicates an active movement with great scope for extension. It is too soon to tell with any certainty what prospects it has of lasting success, but the report for I9I2 ought to throw some light upon it, because that was a wet year following a dry one. During I9II, which was a very dry and hot season, 99 tenants gave up and 20 had notice to quit. The proportion is very small, and must be considered satisfactory in view of the drought. But the real test comes with a wet season. The two great enemies with which British agriculture has had to contend have always been bad seasons, which are more often wet than dry, and low prices; and the former 
is the more formidable of the two. Several wet seasons in close succession have brought it to ruin at various periods in the past, and the smaller men naturally give way first. Those who make comparisons with other countries generally forget this all-important factor. Bad seasons occur in other countries, but less often; nowhere else is the weather so irregular, uncertain, and capricious, so apt to upset all calculations. The new smallholdings movement has not yet had to face either test. Farming in general has been looking up with the rise in prices and the weather has not been disastrous, though it came very near to it last year.

Even in favourable circumstances, however, it is necessary that the man and the soil should be suited to cultivation on a small scale and the situation such as to make marketing sufficiently easy. These conditions can be secured more or less effectively by judicious selection, but it is doubtful if their importance is sufficiently realised. Many experiments in small holdings have failed from ignorance or neglect of them. With regard to the man, in addition to such qualities as industry and thriftiness knowledge is essential. Small holdings are most successful where that type of cultivation has been longest established and is best understood. But lack of experience can be made 
good to some extent by instruction and in connection with the new movement increasing attention is being directed to the need of education in special branches of agriculture.

\section{Co-operation.}

When all such conditions have been fulfilled and sufficient capital is also available, the economic position of the small man must still remain weak, unless he has some other business or means of subsistence, as a good many have ; and the remedy for individual weakness is combination. Co-operation is a great help in all circumstances, but in adverse ones it is almost a necessity. The classical examples of what can be done with its help are Denmark and Ireland, two predominantly agricultural countries with comparatively little wealth or resources drawn from other activities. The story of co-operation in Ireland has recently been told in some detail in The Times (March I7), and a brief reference must suffice here. Started in I8S9 and gradually built up under difficulties and in the face of apathy or hostility, mainly through the ceaseless efforts of Sir Horace Plunkett and a few friends, agricultural cooperation has developed into a great, highly successful, and progressive movement, which has at length been recognised by the Government in the recent decision to allow the Irish 
Agricultural Organisation Society a grant from the Development Fund. There are at present 955 societies with a membership of 97,000 . The great majority of them are engaged in dairy farming, which lends itself with peculiar readiness to co-operative effort in the form of creameries, but there are also a considerable number of societies engaged in arable farming and in poultry-keeping. Another important feature is the establishment and growth of credit societies on the German model, so far as the English law permits. Under the influence of co-operation and land purchase the area of cultivated land in Ireland has been steadily increasing, while that of Great Britain has been steadily diminishing. Between Igog and IgII the former increased by 127,666 acres and the latter decreased by 88,4I 5 acres.

With regard to Denmark, we can only refer readers to the graphic and interesting account given by Sir H. Rider Haggard in his recently published book Rural Denmark and Its Lessons. Co-operation has been the efficient agent in placing Denmark in that unique position with regard to the agricultural population to which attention has been drawn in a previous chapter. 
Co-operation in Great Britain.

It must not be inferred that what has been done in Ireland and Denmark can be repeated straightway in Great Britain, where the conditions are different. But co-operative societies and credit banks have played a great part in the maintenance and development of agriculture in other countries where the conditions more nearly resemble those of Great Britain, and notably in Belgium and Germany. Their value in assisting small cultivators cannot be denied, and they are catching hold in Great Britain. From the latest official report, which brings the statistics only down to I909, the number of agricultural productive societies had then increased from eight in I\$95 to 23 in I909, and the distributive societies from five to 176 . It is true that they are very small. The total membership of the former was only I, 2I 6 and of the latter 17,449 , but they are growing. There are also 44 credit societies in England and Wales, and a central Agricultural Organisation Society, which receives a grant from the Development Fund. In connection with the small holdings movement considerable and growing activity has been shown since the Acts of $1907-8$ in the formation of associations for taking up small holdings on a cooperative plan. Down to the end of Igri over 4,500 acres had been let to 39 associations 
and sub-let to 732 members. This appears to be a very promising line of advance, tending to the formation of groups of small holderscolonies, as they are called on the Continent -advantageously situated and strengthened by common operations in the purchase of seeds, manures, plant, and stock, in the marketing of produce, and the provision of technical instruction.

\section{Limitations of Smali Holdings.}

In sum, there are signs of promise for the revival of rural life in this direction. But its possibilities are limited. It is quite unsuited to some parts of the country and to some branches of farming. It will not, in particular, increase the home-grown supply of corn, which can only be reared by farming on a larger scale ; and the same limitation applies in some measure to meat. There is a certain danger that the compulsory extension of small holdings, if pursued without regard to the final object, which is the best use of the soil, may do more harm than good. Applicants naturally look out for the best land in their neighbourhood, and that is naturally in the occupation of the best farmers. It is argued that a small piece taken out of a goodsized farm will not hurt anybody when compensation is paid. But there are many goodsized farms which depend for their success on 


\section{DRAWBACKS}

a comparatively small portion, of superior quality to the rest or more favourably situated. This withdrawn, the balance of cultivation is upset and the farm no longer pays. It is precisely such portions that the smallholder wants to get. This is called picking out the eyes of a farm, and the upshot is not to the advantage of the community. The land is taken from the man who has made the best use of it for that very reason, and its withdrawal prevents him from making the best use of the rest. The risk is avoided when a whole farm is taken up, as has been done in some instances, by a co-operative group of holders. 


\section{CHAPTER VIII}

\section{LAND OWNERSHIP}

ONE of the agricultural conditions which most markedly distinguishes this country from others is the comparatively small proportion of land owned by those who cultivate it. According to an official return published in I906 only 12.4 per cent. of the agricultural land in Great Britain was then cultivated by the owners. In Germany the proportion is 86.I per cent., in France about 60 per cent., in the United States 64 per cent., and in Denmark 88 per cent. In Belgium the proportion is given by Mr. Rowntree (Land and Labour) as 35 per cent., but another method of calculation makes it about 50 per cent. These figures, without entering into minor differences and qualifications, sufficiently indicate the exceptional position of Great Britain ; and it appears to be becoming more pronounced. Official statistics on the subject were first collected in I887, and in I888 the proportion of owner-cultivated land in Great Britain was I5 per cent. In I9I2 the proportion in England and Wales was only Io.87 per cent. The Board of Agriculture's report 
for that year does not include Scotland, but the proportion in Scotland is still lower than in England and Wales. Taking the latter alone we find, then, a shrinkage from ${ }_{5} 5$ per cent. to I0.87 per cent. between IS88 and I9I2.

If the number of holdings, instead of the acreage, be taken as the unit of comparison the figures are somewhat different, but the general result is virtually the same.

The Decline of Freehold Farming.

What are the causes of this remarkable difference between Great Britain and other countries in regard to the respective proportions of freehold and tenant farming? They are to be sought in the history of British and foreign agriculture, but they are by no means easy to find. We do not even know when the differentiation from what is assumed to have been a similar agricultural system to that prevailing elsewhere definitely began. The subject was discussed at the recent International Congress of Historical Studies in the presidential address to the Economic History section given by Professor Ashley, who summarised the results of modern research with characteristic breadth and clearness. It is not within the scope of this chapter to follow him through his survey, and still less to criticise it, but the more salient points may be noted. 
One of the results of the most recent research is to discredit the theory that any general system of communal land-owning prevailed in Europe in post-Roman times, and to suggest that from the earliest historical period much land was individually owned. According to this view peasant proprietorship developed under the manor system, and its history on the Continent may be said to be, broadly, one of gradual growth and emancipation. Professor Ashley shows that a peasant proprietary was not created either in France by the legislation of the Revolution or in Germany by that of Stein and Hardenberg at the beginning of the Igth century. In both cases the peasants were there, and the effect of legislation was to make them more independent and to increase their number. In England, where the medieval conditions had been very much the same, they had already to a great extent disappeared during the I 8 th century. Professor Ashley attributes this to Parliamentary government established in $\mathrm{I}_{689} 9$ and the triumph of Whig principles, which put an end to the policy of peasant protection by the Crown and enabled the landed gentry, witi the aid of money gained in trade, to arrange matters to suit themselves, including the formation of large estates and the development of tenant farming. 


\section{SMALL OWNERS}

The lesson to be learnt from this and from the opposite procedure in other countries, and notably in Bavaria, where 95 per cent. of the cultivated land is owned by the cultivators, is that legislation can exercise a strong directive influence in these matters, and if it at one time discouraged freehold farming it can also encourage it at another.

\section{The Small Owner and Economic CONDITIONS.}

But the tendency to legislation is not the whole story. A mass of detailed evidence is given by Mr. Prothero, who virtually confirms Professor Ashley in regard to the influence of Parliamentary government in I689, showing that small owners and freehold cultivators were numerous and increasing in almost all parts of the country a century later. They may not have been peasant proprietors, in the ordinary meaning of the word "peasant" ; they were yeomen farmers, as they are for the most part on the Continent to-day. The following counties are mentioned by various authorities about the end of the $\mathrm{I} 8$ th century as having a large and increasing number of small owners: Norfolk, Suffolk, Essex, Berkshire, Oxfordshire, Nottinghamshire, Hampshire, Wiltshire, Somerset, Devonshire, Gloucestershire, Shropshire, Staffordshire, Cheshire, Derbyshire, and 
Yorkshire. Exceptions were Lancashire, Westmorland, and Warwickshire, and in all these cases the competition of manufacturing towns and the superior openings offered by industry or trade are mentioned. Hertfordshire is another exception.

The cause of this agricultural expansion was undoubtedly the prosperity then prevailing; there was a "boom" in agriculture, due to high prices and improvements in farming. If it had lasted, there seems to be no reason why the number of owning cultivators should not have been maintained and augmented. But it collapsed suddenly with the end of the Napoleonic war and the subsequent fall of prices. Intense depression set in, aggravated by excessive taxation, and lasted for 20 years. It was in this period, which is vividly described by Mr. Prothero, that the small freeholders disappeared most rapidly. All classes engaged in agriculture suffered, but this class was to a great extent wiped out. "To freeholders, whether gentry, yeomen farmers, or peasant proprietors, the Napoleonic war, with its crushing load of taxation and subsequent collapse of prices, had been fatal," says Mr. Prothero, and he quotes the contemporary evidence of Glover, who wrote in I8I7 about the ruin of the yeomen farmers. They had to sell, but the "purchasers were not men of their own class. 
After ISI2 small capitalists no longer invested their savings in land. Their place as buyers was taken by large landowners or successful traders." The effective influence that enforced the change was economic pressure.

\section{Part Played By Large Landowners.}

The changes and chances which British agriculture has since undergone have all tended broadly to confirm the economic necessity of the large and wealthy landowner as a factor in maintaining the industry. When the depression just described passed away and agriculture began to revive, leading up to the period of prosperity that set in after IS 50 , a great transformation of farming methods was in progress entailing costly improvements which small owners could not afford. An enormous amount of capital was sunk in improving land and providing buildings and plant. And again when the long depression set in after IS 74 , and farmers were only able to carry on with reduced rents, many were nursed through it by owners whose wealth was derived from other sourcesfrom coal mines, manufactures, trade, and urban property. The tenants of embarrassed owners who could not afford such help were often ruined. The state of things is reflected in the income-tax returns. The gross income. 
derived from the ownership of lands fell steadily, from an average of $£ 59,4 \mathrm{I} 8,844$ in I876-8I to $£ 42,272,403$ in I906-II. It only began to show some signs of recovery in IgIO-II. The real meaning of all this is that through the medium of landowners who possessed other resources than land the agricultural population has got back from trade and industry some portion of that which it was forced to sacrifice in their interests. It got back just enough to exist by; but for that it would have perished wholesale. This condition may have been a necessary stage in the economic evolution of the country, but it is not sound and cannot be permanent.

\section{The Coming Change.}

We seem to be now on the eve of another large change in which an expansion of ownership may again play an important part. But, it may be asked, what chance can small proprietors have if the view just indicated is correct? Will they not be liable to be swept away again? Their economic insecurity is, indeed, one of the arguments urged against any attempt to promote them. But here we may find an answer on the Continent and in one part of the United Kingdom. Continental countries, as this chapter began by showing, have not undergone the same transformation; 
they have managed to keep and to strengthen their small freeholders. How is this? One reason is that agriculture has been protected, which means that it has been politically strong enough to protect itself. But it has not yet anywhere had to meet the same pressure as in this country. If it had-if the other interests had been as overwhelming as they were here, and the demands of the urban population had been equally insistent-we may surmise that events would have followed a somewhat similar course, though not an identical one, because other conditions differ. The signs now gathering in some Continental countries, and notably in Germany, suggest that agriculture will not be able indefinitely to maintain the bulwarks it has set up for its own protection, and that large changes are in prospect.

This factor, however, is only one, and the case of Denmark shows that some branches of agriculture at least can be successfully carried on by small freeholders without it. The secret is co-operation, to which protected agriculture has also had recourse in other countries. The remedy for individual economic insecurity is combination, as we said in the previous chapter in connexion with small holdings; and it applies to small owners even more than to small tenants. 
OWNERS OR TENANTS.

A violent and unnecessary controversy has arisen on the respective merits of the two systems. It is not inspired by interest in the welfare of agriculture or the best use of the soil, which should be the objects in view, but by quite extraneous motives. Both systems have always existed and both are desirable. One suits some men and some conditions best, the other suits others. But so far as keeping the population on the land is concerned there is no question that for the most energetic and enterprising men the prospect of ownership is the most powerful of attractions and its realisation the strongest tie. It is this which is attracting so many to Canada and elsewhere. It is not an easier life or the pleasures of the town, because they are going to a harder life far away from the town; it is the prospect of independence and the opportunity of realising themselves. No possible rise in wages or improvement in housing can weigh against this attraction. And if it be possible, why should they not have it at home? They are the very men to make the utmost of the soil which they hope to call their own. They are said to be few because the applicants are few under the Small Holdings Acts. But the emigration returns, which have aroused the cry that large numbers of the best men are leaving the land and fleeing 
from the country, prove that they are not few. The paucity of applications under the Small Holdings Acts is the strongest argument for altering the procedure. When the facilities offered are better the applicants are very numerous. The Duke of Bedford had 500 applicants for $I 7$ holdings at Maulden. Even if they really were few, that would be no reason for discouraging those there are, but quite the contrary. There are other men of different temperament or differently situated who do not wish to be owners and prefer to be tenants. By all means let them be catered for too. The two classes are not mutually exclusive.

\section{The Re-Creation of Village Life.}

Of course, the case of small owners does not cover the whole question of ownership. The varying conditions of farming require all sizes of holdings, and the cultivating owner is desirable in all of them because he has more interest in getting the best out of the land than a tenant. At one end of the scale there is the sitting tenant of a large farm who may become its owner, and at the other is the ordinary agricultural labourer who becomes the owner of a small plot of ground. In France, which of all industrial countries has retained the largest proportion of its population on the soil, the majority of the 
agricultural labourers are also. small owners on their own account, and it is this which attaches them to the soil.

No class should be left out of view ; but perhaps the most promising line now opening out for the regeneration of village.life is that of colonisation by groups of cultivators in cooperation; and experience goes to show that owners, who have to depend on themselves, are more ready to co-operate than tenants. Both in Denmark and in Ireland successful co-operation rests on ownership. The time seems ripe for this movement, which is not the same thing as the peasant proprietary discussed by the Duke of Richmond's Commission forty years ago. The circumstances also are different. The acute depression is passed and the omens are more favourable. The land has been brought into a better condition than ever before; the costly improvements - reclamation of waste, drainage, fencing, road-making-have been accomplished, and a great extension of transport facilities is coming on. With united, sincere, and judicious effort a new and more hopeful phase may be gradually opened up for British agriculture.

GARDEN CITY PRESS LTD., LETCHWORTH, HERTS. 



\section{UNIVERSITY OF CALIFORNIA LIBRARY \\ Los Angeles}

This book is DUE on the last date stamped below. 

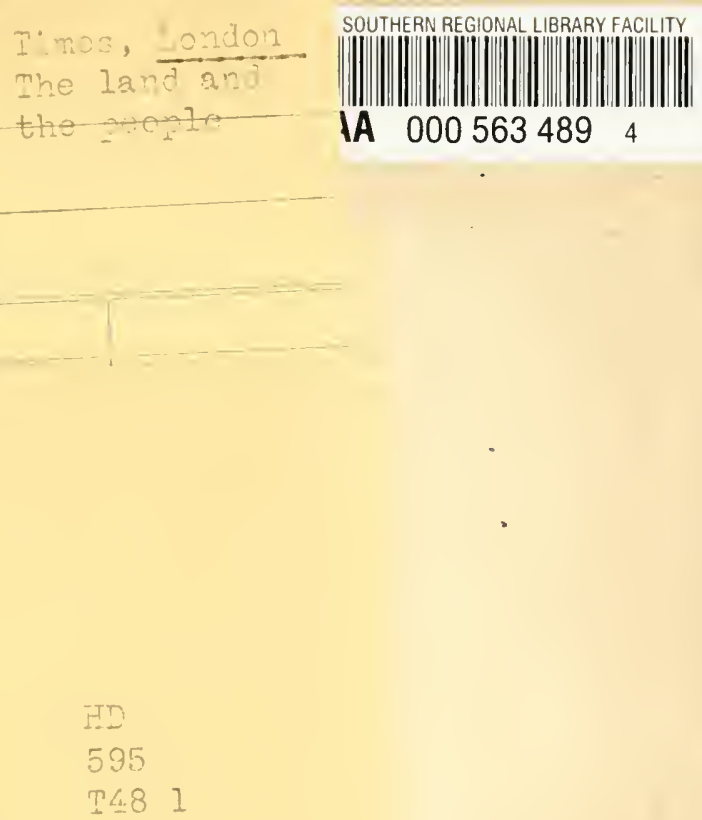


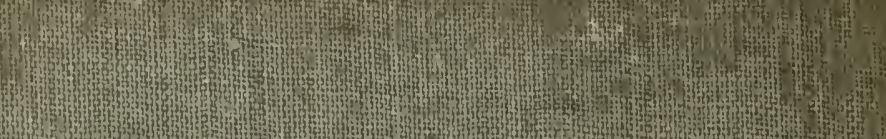

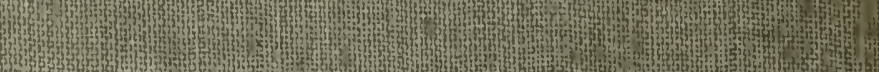
- 5 t

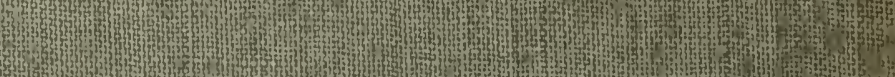

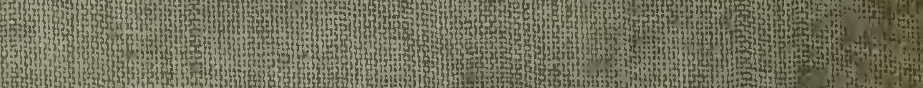

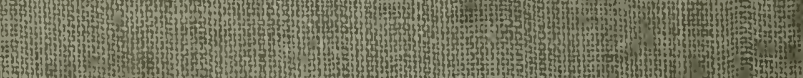
(2) 20. (2) -3:2: (2) (2) (2:2: (2) (2.) (25) (15:4) s.t. 12: (1) H. 4. (1) 